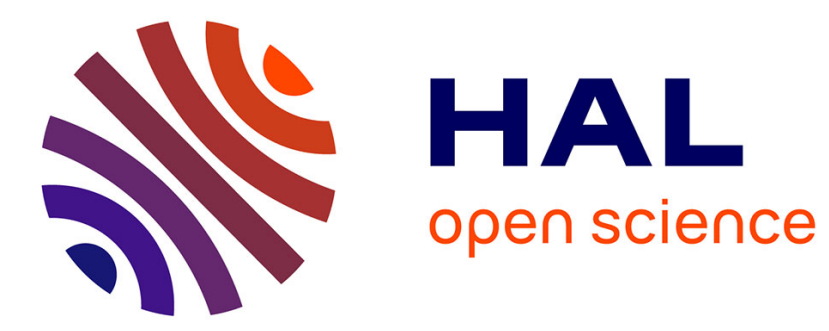

\title{
Differences in spatial and seasonal patterns of macrophyte assemblages between a coastal lagoon and the open sea
}

\author{
A. Pérez-Ruzafa, M.I. Hegazi, I.M. Pérez-Ruzafa, C. Marcos
}

\section{To cite this version:}

A. Pérez-Ruzafa, M.I. Hegazi, I.M. Pérez-Ruzafa, C. Marcos. Differences in spatial and seasonal patterns of macrophyte assemblages between a coastal lagoon and the open sea. Marine Environmental Research, 2008, 65 (4), pp.291. 10.1016/j.marenvres.2007.11.008 . hal-00501931

\section{HAL Id: hal-00501931 \\ https://hal.science/hal-00501931}

Submitted on 13 Jul 2010

HAL is a multi-disciplinary open access archive for the deposit and dissemination of scientific research documents, whether they are published or not. The documents may come from teaching and research institutions in France or abroad, or from public or private research centers.
L'archive ouverte pluridisciplinaire HAL, est destinée au dépôt et à la diffusion de documents scientifiques de niveau recherche, publiés ou non, émanant des établissements d'enseignement et de recherche français ou étrangers, des laboratoires publics ou privés. 


\section{Accepted Manuscript}

Differences in spatial and seasonal patterns of macrophyte assemblages between a coastal lagoon and the open sea

A. Pérez-Ruzafa, M.I. Hegazi, I.M. Pérez-Ruzafa, C. Marcos

PII:

S0141-1136(07)00147-X

DOI:

10.1016/j.marenvres.2007.11.008

Reference:

MERE 3157

To appear in:

Marine Environmental Research

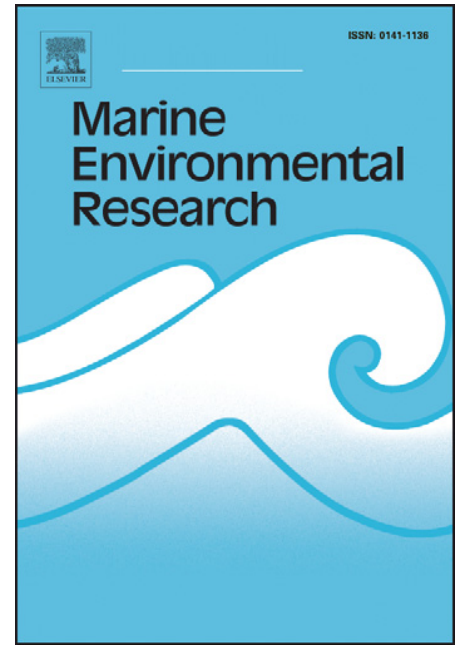

Received Date: $\quad 5$ July 2007

Revised Date: $\quad 17$ November 2007

Accepted Date: $\quad 19$ November 2007

Please cite this article as: Pérez-Ruzafa, A., Hegazi, M.I., Pérez-Ruzafa, I.M., Marcos, C., Differences in spatial and seasonal patterns of macrophyte assemblages between a coastal lagoon and the open sea, Marine Environmental Research (2007), doi: 10.1016/j.marenvres.2007.11.008

This is a PDF file of an unedited manuscript that has been accepted for publication. As a service to our customers we are providing this early version of the manuscript. The manuscript will undergo copyediting, typesetting, and review of the resulting proof before it is published in its final form. Please note that during the production process errors may be discovered which could affect the content, and all legal disclaimers that apply to the journal pertain. 
1 Differences in spatial and seasonal patterns of macrophyte assemblages between a

coastal lagoon and the open sea

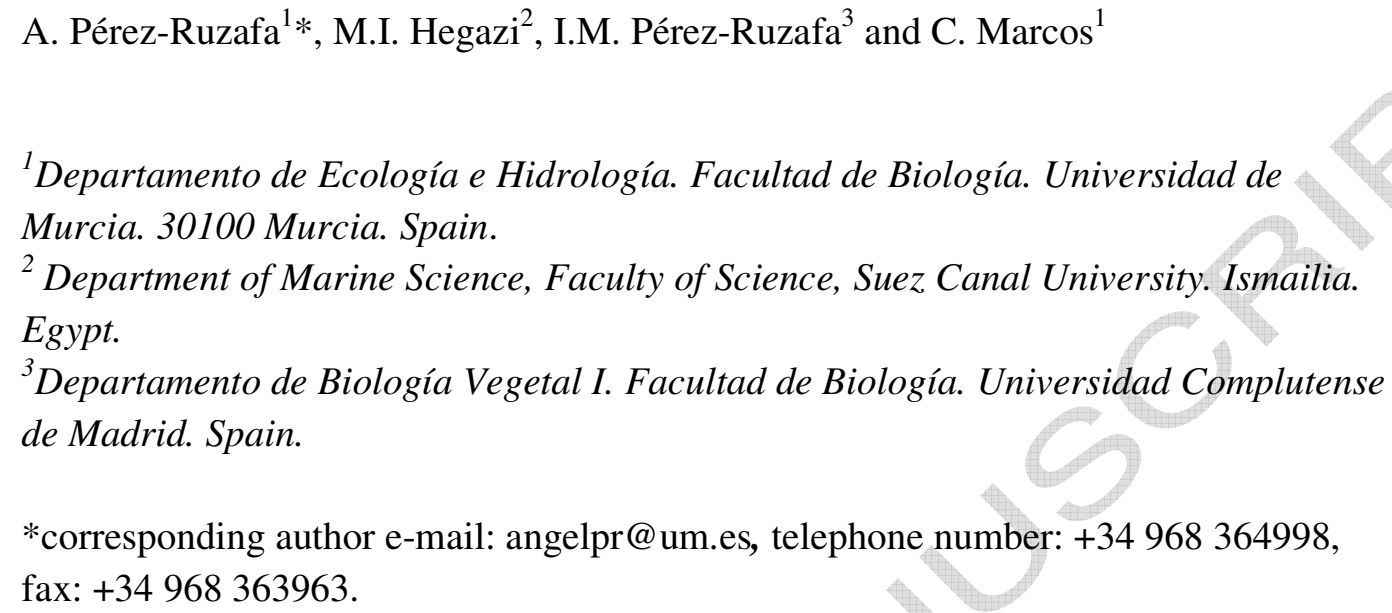

Although benthic macrophytes must be considered in monitoring programs to establish the ecological status of transitional and coastal waters in the European Union, the patterns of variability in species composition of macrophyte assemblages in Mediterranean coastal lagoons has scarcely been studied. In this work the spatial (both vertical and horizontal) and seasonal dynamics of macrophyte assemblages in a coastal lagoon (Mar Menor) are compared with those of open coastal assemblages in the SW Mediterranean to analyze any biological variability in lagoon assemblages and the factors that determine such variability. Different assemblages, characterized by well defined groups of species, can be described according to their isolation from the open sea and the type of substratum; at the same time, a vertical zonation pattern, similar to that found in all marine communities but more compressed, exists. This implies that when applying the EU Water Framework Directive or assessing environmental impact, a lagoon should not be considered spatially uniform and unique unit but as a mosaic of assemblages.

Keywords: macrophyte assemblages; coastal lagoons; spatio-temporal variability; environmental impact assessment; Mar Menor

\section{Introduction}

Coastal lagoons have traditionally been considered as transitional systems between continental and marine domains (Bianchi, 1988 a), a consideration that has gained in importance in the context of the Water Framework Directive (WFD) of the European Union. The $W F D$ requires scientific and biological criteria to establish the basis for 
typifying coastal ecosystems and transition waters (lagoons and estuaries). In the case of the former, such criteria have long been established, while for transitional waters they do not exist. The proposed criteria are not the same for both categories and, while there is no doubt about the nature of estuaries, there is some controversy as to whether lagoons should be treated as coastal or transitional waters.

Furthermore, in accordance with the WFD, the ecological status of a water body must be evaluated using biological indicators, including macroalgae and seagrasses in the context of hydromorphological and physico-chemical conditions (Ballesteros et al., 2007). In general, benthic macrophytes are considered good indicators of water quality and different indices and methodologies based on them have been proposed for assessing the ecological status of coastal and transitional waters in the context of the WFD (Pasqualini et al., 2006; Austoni et al., 2007; Ballesteros et al., 2007; Pinedo et al., 2007; Wells et al., 2007). However, their application to transitional waters presents difficulties as a consequence of changes in species composition along the natural gradients of environmental conditions in these ecosystems (Wilkinson et al., 2007). Some recent proposals look at the problem in estuarine transitional waters but explicitly exclude lagoons (Wilkinson et al., 2007).

Coastal lagoons undergo frequent physical and chemical disturbances and fluctuations (Unesco, 1981) and are consequently naturally stressed habitats (Barnes, 1980). They are characterized by particular features, such as shallowness, relative isolation from the open sea, usually as a result of coastal barriers that maintain some communication channels or inlets, and the presence of boundaries with strong physical and ecological gradients (Unesco, 1981). Due to their shallowness, bottoms are usually well irradiated, while currents and hydrodynamics are closely conditioned by bottom topography and wind affects the entire water column, promoting the resuspension of materials and nutrients from the sediment surface layer. Because of these characteristics, coastal lagoons are usually among the marine habitats that show the greatest biological productivity (Alongi, 1998).

Pérès and Picard (1964) considered Mediterranean lagoon systems as a well differentiated and unique homogeneous community, the so-called euryhaline and eurythermal biocenoses. This consideration was maintained by later authors, such as Augier (1982) and Guelorget and Perthuisot (1983), and in the habitat lists of conservation agreements, including OSPAR, Barcelona and Eunis. Although benthic macrophytes must be considered in monitoring programs to establish the ecological status of transitional and coastal waters (European Union, 2000), and despite a number of papers that study species composition in transitional waters, the patterns of variability of macrophyte assemblages in coastal lagoons have scarcely been studied in the Mediterranean. A few studies have explicitly characterized different communities or phytocoenoses according to the water characteristics in one or several lagoons (Lovric, 1979; Zouali, 1979; Chassany de Casabianca, 1980) or described vertical zonation patterns (Cecere et al., 1988, Sfriso, 1987). However, some papers that analyze the 
differences in species distribution or biomass related to environmental variables such as salinity or trophic conditions (Sfriso et al., 2003; Curiel et al., 2004; Lin and Hung, 2004), do not consider the possibility of several communities existing in lagoons, similar to those existing in coastal marine habitats, or, when referring to heterogeneity, assume a single algal community for the whole lagoon (Cecere et al., 1992). In general, and in accordance with the proposal of Péres and Picard (1964), benthic macrophytes are considered to constitute a single assemblage within each lagoon (Chassany de Casabianca, 1979; Nagy, 1979; Skolka and Tiganus, 1985; Cecere et al., 1991; Bachelet et al., 2000; Mouillot et al., 2005). Because of this, such habitats are managed as units, with decisions adopted at lagoon scale, whereas different areas of each lagoon might require different management options (De Biasi et al., 2003).

Inter-lagoon variability has been attributed to many biotic and abiotic factors (Ross and Epperly, 1985; Yañez-Arancibia et al., 1985) and, as regards the functioning of coastal lagoon ecosystems, several proposals have been made using different criteria to classify and typify these environments. Among these proposals, some of the most important use salinity as the main parameter (Anonymous, 1959; Petit, 1953; Por, 1972). Using salinity as a descriptor involves considering autoecological criteria as a classification basis, making the use of indicator species feasible (Bianchi 1988a, 1988b).

However, intra-lagoon variability also exists and has been related to depth (Sfriso, 1987; Pasqualini et al., 2006), type of substratum (Pérez-Ruzafa et al., 1989, 2006) and, especially, confinement gradient sensu Guelorguet and Perthuisot (1983) an indicator of the degree of marine influence on lagoon ecosystems (Mariani, 2001).

Kjerfve (1994) also sub-divided coastal lagoons into three geomorphic types (choked, restricted and leaky), which the author considered as three points along a spectrum of water exchange with the coastal sea. The rate and magnitude of oceanic exchange reflects both the dominant forcing functions and the time-scale of hydrological variability.

The physical gradients within the lagoon environment arising from these exchange rates have been related to biological gradients in species richness, abundance and productivity. In the early 1980's, Guelorget and Perthuisot (Guelorget and Perthuisot, 1983; Guelorget et al., 1983) rejected salinity as an essential parameter for explaining the observed gradients in density, biomass, species richness and diversity and proposed that zonation patterns and species distribution inside the lagoons were determined by the degree of confinement, a parameter which represents the turnover time of marine water and the impoverishment in some oligo-elements of marine origin. Later, as regards the structure of faunal lagoon assemblages, Pérez-Ruzafa and Marcos (1992, 1993) suggested that, rather than vitamin and oligo-element recycling, the main factor explaining them along a confinement gradient would be colonization rates by marine species. The species composition in each lagoon site will be the result of equilibria, in the context of interspecific competition between marine and lagoon species. 
According to this, lagoon assemblages would be the result of complex environmental and biological interactions, and not only a response to the extreme physico-chemical conditions or to a single horizontal gradient. The structure and composition of lagoon communities would be better described by sinecological criteria and the same structural parameters as in open coastal areas. In this way, multifactorial approaches and structural indices of lagoon assemblages could be used to describe the ecological status of a particular lagoon site and community.

In this work, we study the spatial (both vertical and horizontal) and seasonal dynamics of macrophyte assemblages in a coastal lagoon, compared with those of open coastal assemblages in the SW Mediterranean, to analyze biological variability in lagoon assemblages, the factors that determine this variability, and the degree of differentiation between lagoon and open coastal macrophyte assemblages. The data used for this work pre-date the changes that have occurred in the trophic status of the Mar Menor waters in the last ten years (Pérez-Ruzafa et al., 2002) so that they are useful for the establishment of reference conditions in this lagoon for the implementation of the WFD.

\section{Material and methods}

\subsection{Study area}

The Mar Menor is a hypersaline coastal lagoon, with a surface area of $135 \mathrm{~km}^{2}$ located on the southwestern Mediterranean coastline (37\%42'00" North - 0047'00" West) (Fig. 1) with a mean depth of $3.6 \mathrm{~m}$ and maximum of about $6 \mathrm{~m}$. The salinity of the lagoon waters range from 42 to 46 . The bed sediment grain size composition is predominantly muddy and sandy, with some areas of natural rocky bottoms around islands and some calcareous and volcanic outcrops. Muddy bottoms, which cover both the whole central area of the lagoon and the shallow zones showing lower hydrodynamism, are covered by a dense meadow of the algae Caulerpa prolifera (Forsskål) J.V. Lamouroux or patches of the sea grass Ruppia cirrhosa (Petagna) Grande. Sandy bottoms (with sand content up to $89 \%$ ) are located at the margins of the basin and in the small bays surrounding the islands, in which sparse patches of the phanerogame Cymodocea nodosa (Ucria) Asch. grow.

\subsection{Sampling methods}

To study the spatial and seasonal patterns of lagoon macrophyte assemblages, three localities (two inside the lagoon and another on the Mediterranean coast) were sampled monthly from June 1995 to October, 1996. Sampling sites were located where there was no significant waste input from human activity based on our knowledge of the main sources of agricultural runoff inputs (Pérez-Ruzafa et al., 2000), the available information on the distribution of urban wastes, coliform bacteria and heavy metals in sediments and organisms (Marcos, 1991) and visual survey. The outer locality was located at Cala Fría in the Cabo de Palos Marine Reserve, close to the Mar Menor lagoon (Fig. 1), in a relatively wind-protected area to avoid excessive differences in 
wave exposure compared with the lagoon localities. Of the two inner localities, one was close to the main channel through which water exchange takes place, and the other one was located in the southern basin, considered the most isolated and confined area of the lagoon (Pérez-Ruzafa, 1989; Pérez-Ruzafa et al., 2004, 2005a, 2005b).

Macrophyte assemblages were sampled monthly by diving. All macrophyte species were hand-collected in a square of $400 \mathrm{~cm}^{2}(20 \times 20 \mathrm{~cm})$, a size considered representative for midlittoral and infralittoral Mediterranean macrophyte communities (Cinelli et al., 1977; Cecere et al., 1988; Ballesteros, 1992, 1993). Two replicates, randomly distributed, were taken for each sample and the species were determined at specific level. One of the samples was used for biomass estimations for this work and the second was used for pigment extraction. Sampled open coastal assemblages include midlittoral photophilous algae on rock (MPhR), infralittoral photophilous algae on rock (IPhR), infralittoral sciaphilous assemblage on rock (IScR) and Posidonia oceanica meadow (PM). Inside the lagoon, samples were taken of MPhR a few centimetres under the mean water level and at $1.5 \mathrm{~m}$ depth, both in well illuminated (IPhR) and in sciaphytic environments (IScR). Furthermore we sampled the Cymodocea nodosa meadow (CyM) on sand and the Caulerpa prolifera meadow (CaM) on mud.

Macrophyte samples were kept in a cool-box and taken to the laboratory, where samples were washed using clean sea water to remove sediments and then spread out in a tray containing sea water to estimate the percentage of cover for each species according to Cox (1981). After species level identification, the standing crop biomass for each species was measured in terms of both dry weight (DW) and ash free dry weight (AFDW). DW determination was made by drying to constant weight ( $24 \mathrm{~h}$ ) in an oven at $110^{\circ} \mathrm{C}$, and subsequently AFDW was determined by burning in a furnace at $450^{\circ} \mathrm{C}$ for $6 \mathrm{~h}$. Weight was calculated with a precision of $\pm 0.0001 \mathrm{~g}$. The classification and nomenclature in this study follows that adopted by Guiry and Guiry (2007).

Key hydrographic (hydrodynamism, nutrient concentration in water column, $\mathrm{pH}$, temperature and salinity) and sediment characteristics were recorded monthly at the three stations during the study period.

The water column is well mixed and there were no significant differences in temperature or salinity with depth (Pérez-Ruzafa, 1989), so that water samples for environmental variables were taken at an approximate depth of $1 \mathrm{~m}$ with a Niskin bottle, or by pumping. Samples for nutrient analysis were kept in the dark at $4^{\circ} \mathrm{C}$ in the field and stored at $-28^{\circ} \mathrm{C}$. Nitrate $\left(\mathrm{NO}_{3}-\mathrm{N}\right)$, nitrite $\left(\mathrm{NO}_{2}-\mathrm{N}\right)$, ammonium $\left(\mathrm{NH}_{4}-\mathrm{N}\right)$ and phosphate $\left(\mathrm{PO}_{4}-\mathrm{P}\right)$ were determined, following the methods described by Parsons et al. (1984). To determine salinity a Beckman RS 7B salinometer was used, while $\mathrm{pH}$ measurements were made with a pre-calibrated meter.

At each site, hydrodynamism (as represented by wave exposure) was estimated according to Keddy (1983) as follows: 
224

225

226

227

228

229

230

231

232

233

234

235

236

237

238

239

240

241

242

243

244

245

246

247

248

249

250

251

252

253

254

255

256

257

258

259

260

261

Wave Exposure $=\sum\left(\right.$ mean wind velocity ${ }_{22.5^{\circ}} *$ wind frequency $y_{22.5^{\circ}} *$ effective fetch $\left._{22.5^{\circ}}\right)$

where the effective fetch $\left(\mathrm{F}_{\mathrm{e}}\right)$ is the direct fetch $(\mathrm{F})$, or distance in kilometres along which the wind blows from each direction, corrected by fetches in directions of less than $45^{\circ}$ using the equation,

$\mathrm{F}_{\mathrm{e}}=\left[\mathrm{F}_{(\alpha)} * \cos \alpha+\mathrm{F}_{(\alpha+22.5)} * \cos (\alpha+22.5)+\mathrm{F}_{(\alpha-22.5)} * \cos (\alpha-22.5)\right] /[\cos \alpha+2 *$ $\cos (\alpha+22.5)]$

where $\alpha$ is equal to 0 for each $\mathrm{F}_{\mathrm{e}}$ calculated.

Sediment samples were taken by diving in the communities on soft substrata, such as sandy bottoms with Cymodocea nodosa or Posidonia oceanica meadows, and muddy bottoms covered by Caulerpa prolifera meadows. Samples were hand taken from the top $10 \mathrm{~cm}$ of the substrata using a shovel, stored and transported in darkness and cold in polyurethane bags. At the laboratory they were dried at room temperature. During this process they were stirred to break lumps before being sifted to a size of $2 \mathrm{~mm}$. Grain size distribution was determined in sub-samples by the Bouyoucos hydrometer method (Soil Conservation Service, 1973) after dispersion of clusters by mechanical stirring in a sodic-hexametaphosphate and $\mathrm{Na}_{2} \mathrm{CO}_{3}$ solution. Previously, salts were eliminated by washing and centrifugation and organic matter was eliminated by hydrogen peroxide treatment. Grain size classification was made according to the International Association for Soil Science (Duchafour, 1975). Organic carbon was determined by the WalkleyBlack method (Buchanan, 1984) and total nitrogen by the Kjeldahl method (Bremmer, 1965).

\subsection{Data analyses}

Macrophyte assemblage structure was specified for each sample according to its species richness and species composition, abundance (percentage of cover and biomass), and Shannon-Wiener's diversity $H^{\prime}$. For each species we estimated its relative dominance $(\% \mathrm{D})$ in each assemblage and frequency of occurrence $(f)$, classifying them into frequent $(\mathrm{F})(f \geq 40 \%$ corresponding to more than 7 months during the study period), seasonal (S) $(18 \% \leq f<40 \%)$ and occasional $(\mathrm{O})(f<18 \%)$ species.

To study the affinity between samples, Jaccard's coefficient (Day et al., 1971; Margalef 1974) was applied using presence-absence data. Spatial and temporal variations in the structure of the vegetation assemblages were assessed by non-metric multi-dimensional scaling (MDS) and analyses of similarities (ANOSIM), using the statistical software PRIMER 5.0 (Clarke and Warwick, 2001) and similarity matrices based on the BrayCurtis similarity coefficient generated with biomass (DW) data. Values were squareroot transformed before the analyses so that each species contributed fairly evenly to each analysis (Clarke and Green, 1988). Pairwise ANOSIM comparisons were made between all groups, using 10000 simulations in each case. Furthermore, site ordination 
was also conducted using detrended correspondence analysis (DCA) on the records of biomass (DW) of each species using the CANOCO 3.15 (ter Braak, 1997).

To explore the spatial variation of macrophyte assemblages in relation to environmental characteristics, we performed a Canonic Detrended Correspondence Analysis (DCCA) (ter Braak and Prentice 1988) using both square-root transformed cover and biomass (DW and AFDW) data. This analysis was applied because the length of the gradient covered by the first axis, when a Detrended Correspondence Analysis was performed on the species matrix, was higher than 2 in units of standard deviation, and so the response of the species to the environment gradient could not be considered lineal (Jongman et al., 1987). The ordination results of are displayed by scaling the axes and adjusting the species' scores to the species' variance: the resulting scores are correlations between species and eigenvectors. The relative contribution of each variable to the ordination established by the DCCA was evaluated by Monte Carlo permutation test after performing a forward selection of variables at the $0.1 \%$ level of significance. All these calculations were made using the CANOCO v. 3.15 package (ter Braak, 1990).

To quantify the spatial and temporal variation in macrophyte assemblages, data for biomass (total, and per species), species richness, diversity and habitat descriptors were analysed using 3-factor analysis of variance (Underwood, 1997), under the null hypothesis that each variable tested is homogeneous across the different localities, assemblages and time. Monthly data were considered as replicates in each season.

All factors, community ( $\mathrm{c}=2$, photophilous midlittoral and infralittoral), season ( $\mathrm{s}=5$, from summer 1995 to summer 1996, both included) and locality (l=3, Cabo de Palos, Estacio and El Ciervo island) were fixed orthogonals. For the Caulerpa prolifera meadow, two factor (season and locality) analysis of variance was performed. Prior to analysis, homogeneity of variances was checked using Cochran's test.

When the results of the analyses were significant, Tukey's Honestly Significant difference (HSD) tests were performed in order to identify the significantly different means.

\section{Results}

\subsection{Variation of environmental parameters}

The environmental conditions of the three localities differed (Fig. 2, Table 1). Although water temperature and the suspended solids content were similar, they differed in salinity, wave exposure and nutrient concentration (Table 2). Temperature showed a marked seasonal pattern, with maximum temperatures in August $\left(28^{\circ} \mathrm{C}\right.$ at El Estacio and $\mathrm{El} \mathrm{Ciervo} \mathrm{island,} \mathrm{and} 26^{\circ} \mathrm{C}$ at Cabo de Palos) and minimum in January and February $\left(13^{\circ} \mathrm{C}\right.$ at Cabo de Palos and 10 and $9{ }^{\circ} \mathrm{C}$ at El Estacio and El Ciervo island, respectively). Water transparency was high, Secchi disc visibility reaching the bottom in all localities. Suspended solids ranged between 0.01 and $0.18 \mathrm{~g} / \mathrm{L}$, with no seasonal 
pattern, and did not differ greatly between localities. The greatest difference in salinity was between Cabo de Palos (39-40) and the two lagoon localities (44-47 at El Ciervo island; $42-47$ at El Estacio). There was also some time lag in the minimum salinity in the three localities, Cabo de Palos reaching minimum levels in November, El Ciervo island in December-January and El Estacio in February.

Wave exposure was higher in Cabo de Palos than in the lagoon localities, and the interaction Locality * Season $(p<0.0001)$ was significant as a consequence of seasonal changes in wind regime and because the three localities did not have the same orientation.

In general, waters were oligotrophic in Cabo de Palos and had a slightly higher nutrient concentration in the lagoon. Nitrate was the main nitrogen compound, ranging between 0.10 and $0.39 \mu \mathrm{M}$ in Cabo de Palos, 0.02 and $0.72 \mu \mathrm{M}$ in El Ciervo island and, 0.34 and $3.18 \mu \mathrm{M}$ at El Estacio. Maximum values were recorded in summer in the Mar Menor localities in the two sampled years and in summer (1995) and autumn (1996) in Cabo de Palos. Minimum values were reached in winter at all sites. The differences between localities were significant $(p<0.0001)$, and the interaction Locality * Season $(p<0.05)$ indicated that seasonal patterns differed among localities.

Phosphate showed highest values at El Ciervo island $(0.67-2.38 \mu \mathrm{M})$, while the lowest values were found in Cabo de Palos $(0.19-0.66 \mu \mathrm{M})$. El Estacio showed intermediate values of $0.23-0.99 \mu \mathrm{M}$. Differences were significant for the factors Locality $(p<0.0001)$ and Season $(p=0.01)$ but not for the interaction, indicating that all localities showed the same seasonal pattern.

\subsection{Macrophytobenthic species composition at the sampling localities}

Midlittoral and infralittoral communities on rocky, muddy and sandy substrata from the Mediterranean (Cabo de Palos), and the Mar Menor coastal lagoon (El Estacio and El Ciervo Island) differed both in species composition and dominance. In total, 72 species (23 Chlorophyta, 17 Ochrophyta, 29 Rhodophyta, 1 Cyanophyta and 2 Magnoliophyta) were recorded (Tables 3, 4). The highest floristic richness was found in Cabo de Palos (56 spp), while 25 species were found at El Ciervo island and 21 at El Estacio. A depthrelated gradient was observed in the assemblage composition of the three sites. The $0 \mathrm{~m}$ level at Cabo de Palos possessed the highest number of species (43), while the lowest number (4) was observed in the Caulerpa beds from both El Estacio and El Ciervo island. 26 species (37.68 \%) were exclusive to the sea, while 13 (18.84\%) (Anotrichium tenue, Boergeseniella fruticulosa, Caulerpa prolifera, Chaetomorpha linum, Cladophora albida, Cymodocea nodosa, Cystoseira foeniculacea f. tenuiramosa, Liebmannia leveillei, Polysiphonia subulata, Spyridia filamentosa, Ulva compressa, Ulva clathrata and Valonia aegagropila were present in the Mar Menor samples only. Among these, Boergeseniella fruticulosa, Chaetomorpha linum, Cymodocea nodosa, Cystoseira foeniculacea f. tenuiramosa and Spyridia filamentosa were exclusive to El 
Ciervo Island and Anotrichium tenue, Polysiphonia subulata, Ulva compressa and Ulva clathrata were exclusive to El Estacio channel.

In terms of biomass, the Posidonia meadow showed the highest mean monthly value (143.80 $\mathrm{g} \mathrm{DW} / 400 \mathrm{~cm}^{2}$ ) while the minimum corresponded to the Caulerpa prolifera meadow $\left(11.97 \mathrm{~g} \mathrm{DW} / 400 \mathrm{~cm}^{2}\right)$ and the midlittoral photophilous assemblage on rock $\left(12.70 \mathrm{~g} \mathrm{DW} / 400 \mathrm{~cm}^{2}\right)$ at El Ciervo Island.

At Cabo de Palos the two shallower levels were dominated by Stypocaulon scoparium and Haliptilon virgatum, the latter becoming less frequent with depth. Neither was present in the lagoon. At $1.5 \mathrm{~m}$ depth, but only in shadow sites, Peyssonnelia squamaria was the dominant species. In the deepest water Posidonia oceanica was the dominant seagrass.

At El Estacio, the $0 \mathrm{~m}$ level was dominated by Cladophora spp and Ulva clathrata, while Chondrophycus tenerrimus dominated this level at El Ciervo island. At depth, over hard substrata the community was dominated by Chondrophycus tenerrimus, and Cystoseira foeniculacea f. tenuiramosa and Cystoseira compressa. Jania rubens was the more important epiphyte algae. At El Ciervo island Cymodocea nodosa meadows (mixed or not with the green alga Caulerpa prolifera, or in patchy outgrowths between boulders) were dominant at all depths, while at El Estacio, a Caulerpa prolifera monospecific meadow was dominant at greater depths.

\subsection{Vegetation assemblage structure}

The hierarchical clustering of presence/absence data performed on a Jaccard matrix for mean seasonal biomass at each sampling site (assemblage) showed a clear separation between sea and lagoon assemblages, with the midlittoral samples from El Estacio and the 1995 summer sample from El Ciervo island close to them (Fig. 3).

At a second level, 10 well defined groups corresponded to the main midlittoral and infralittoral assemblages both in the sea and lagoon environments. Group 1 included all midlittoral Mediterranean samples; group 2 included spring and summer sciaphilous communities on rock at Cabo de Palos; group 3 included Mediterranean infralittoral photophilous samples on rock, except the winter sample, which joined the Posidonia meadow samples, and autumn and winter sciaphilous communities on rock (group 4). Groups 5 to 10 corresponded to lagoon assemblages: El Estacio midlittoral samples (G5), Cymodocea nodosa meadows (G6), autumn and winter midlittoral samples at El Ciervo island (G7), infralittoral photophilous assemblages on rock at El Ciervo island, including spring midlittoral assemblages at this locality (G8), El Estacio infralittoral photophilous assemblages (G9) and Caulerpa prolifera meadows at both El Estacio and El Ciervo island (G10).

The MDS ordination plot based on biomass (DW) data confirmed these results and clearly separated the samples into localities and assemblages (Fig. 4). This indicated 
that the presence/absence of species, rather than their abundance, separates the different groups, and confirms the existence of different assemblages. ANOSIM indicated that these vegetation assemblages differed significantly. Global tests for differences between locality groups showed significant differences between El Ciervo island and Cabo de Palos $(R$-statistic $=0.6, p<0.0001)$ and between El Estacio and Cabo de Palos $(R$ statistic $=0.5, p<0.0001)$, but no significant differences were found between El Estacio and El Ciervo island. These differences became significant for all the pairwaise comparisons between localities when only midlittoral and infralittoral photophilous assemblages on rock (present in all the three localities) were considered $(R$ statistic $=0.91, p<0.0001 ; R$-statistic $=0.996, p<0.0001 ; R$-statistic $=0.739, p<0.0001$; respectively). When comparisons were made between assemblages, the global test was significant (Global R-statistic $=0.938, p<0.0001)$. Pairwise tests were all significant at $p<0.01$ level $(R$-statistic $\geq 0.5)$ except between midlittoral and infralittoral photophilous assemblages, on rock at El Ciervo Island, which were significantly different at $p<0.05$ level $(R$-statistic $=0.238)$.

The diversity values reached by midlittoral assemblages were the highest of all sampled assemblages. Cumulative diversity was 3.26 bits indiv. $^{-1}$ at Cabo de Palos and 2.53 and 2.54 bits indiv. $^{-1}$ at El Estacio and El Ciervo island, respectively.

According to this, the different assemblages were characterized by well defined groups of species at each locality.

\section{Cabo de Palos}

At Cabo de Palos, midlittoral photophilous assemblages (CP_MPhR) were dominated by the frequent species Haliptilon virgatum and Stypocaulon scoparium, which represented 29.5 and $25.5 \%$, respectively, of the total biomass. Dictyota fasciola, Jania rubens var corniculata and Padina pavonica together constituted an additional $21.9 \%$. Infralittoral Photophilous assemblages on rocky substrata (IPhR) were dominated by Cladostephus spongiosus (11.7\%), Stypocaulon scoparium (60.9\%) Haliptilon virgatum (10.6\%), Padina pavonica (6.0\%) and Jania rubens var corniculata (2.8\%), all of them frequent species.

Infralittoral sciaphilous assemblages on rocky substrata (IScR) was only present at Cabo de Palos locality since in the Mar Menor, rocky substrata are hard volcanic crusts with only small holes and crevices (El Ciervo Island) or artificial boulders used to build breakwaters (El Estacio) with too little space and illumination to permit conspicuous algal development. The dominant species were Peyssonnelia squamaria (51.6\%, $f=100 \%)$, Halopteris filicina $(19.8 \%, f=100 \%)$, Haliptilon virgatum $(3.8 \%, f=64.7 \%)$, Flabellia petiolata $(3.1 \%, f=100 \%)$, Halimeda tuna $(2.1 \%, f=76.5 \%)$ and Amphiroa rigida $(1.58 \%, f=41.2 \%)$. Seasonally or occasionally, Corallina elongata $(8.2 \%$, $f=5.9 \%)$ and Mesophyllum lichenoides $(2.23 \%, f=23.5 \%)$ also contributed to the assemblage biomass.

Posidonia oceanica meadows (PM) was also exclusive to the open coastal Mediterranean bottoms. In terms of biomass the community was monospecifically 
dominated by Posidonia oceanica, which contributed to $99.5 \%$ of the total biomass $(f=100 \%)$. Halopteris filicina $(0.3 \%, f=41.2 \%)$ was the only other frequent species in the samples from this assemblage.

\section{El Estacio}

At El Estacio, midlittoral assemblages (EE_MPhR) were dominated by Cladophora albida (37.2 \%), Jania rubens (25.9\%) and Ulva clathrata (12.1\%). However, except the first one, which was frequent, the others can be considered seasonal. Cladophora coelothrix represented only $5.2 \%$ of the total mean biomass but was present during most of the year $(f=52.9 \%)$.

IPhR assemblages were dominated by a nearly mono-specific cover of Jania rubens which represented $84.7 \%(f=100 \%)$ of the total assemblage biomass. Other frequent species were Caulerpa prolifera (6.8\%), Valonia aegagropila $(2.5 \%)$ and Chondrophycus tenerrimus $(0.5 \%)$. Seasonally, Ceramium ciliatum ( $2.1 \%$ of the total mean biomass), Cladophoropsis modonensis (1.6\%), Padina pavonica (0.8\%) and Acetabularia acetabulum $(0.28 \%)$ made significant contributions to the assemblage biomass.

\section{El Ciervo Island}

At El Ciervo Island, the dominant species in midlittoral assemblages (IC_MPhR) were Chondrophycus tenerrimus (45.3\%) and Cladophora albida (23.5\%), both frequent, followed by Cystoseira compressa (8.6\%) and Jania rubens (6.7\%). Cystoseira compressa, being a perennial species, overcomes the unfavourable season with basal parts only and shows a pronounced seasonal cycle at this midlittoral level. Infralittoral photophilous assemblages on rocky substrata were dominated by Chondrophycus tenerrimus (58.2\%), Cystoseira compressa (15.6\%) and Cystoseira foeniculacea f. tenuiramosa (6.7\%), all them with high frequencies of occurrence $(f=100 \%)$. Also frequent but with a lower contribution to the total biomass were Caulerpa prolifera $(3.3 \%, f=88.2 \%)$, Padina pavonica $(4.0, f=94.1 \%)$ Cymodocea nodosa $(3.1 \%, f=76.5 \%)$ and Jania rubens $(4.0 \%, f=64.7 \%)$.

Cymodocea nodosa (CyM) and Caulerpa prolifera (CaM) meadows were only sampled in the Mar Menor lagoon where the former constituted the most conspicuous community on sandy bottoms and the latter on muddy bottoms with a high organic matter content. In terms of biomass, the former was monospecifically dominated by Cymodocea nodosa, which contributed $98.9 \%$ to the total biomass $(f=100 \%)$. Any other species, such as Chaetomorpha linum, Acetabularia acetabulum or Acetabularia calyculus were occasional and, in the last case, linked to the existence of small stones or shells.

On the other hand the Caulerpa prolifera meadow was dominated by this alga which contributes $99.6 \%$ and $97.2 \%$ to the total biomass at El Estacio and El Ciervo island, respectively ( $f=100 \%$ in both cases). At El Ciervo island there were some seasonal contributions from Chaetomorpha linum. 


\subsection{Environmental factors explaining the assemblage composition and structure} When performing the redundancy analyses (DCCA) on the macrophyte species matrix using environmental data as explanatory variables, the cumulative percentage of variance of the species-environment relation for the first two axes reached $59.1 \%$ (Fig. 5). The first axis had an eigenvalue of 0.82 and explained $41.1 \%$ of total variance.

The stepwise forward selection of environmental variables pointed to salinity, temperature, organic matter, wave exposure, depth, phosphate, nitrate, and salinity and temperature stress as having a significant influence on the assemblage structure (Fig. 6). All the samples were distributed in the space defined by the positive parts of axes I and II. The first axis represents a gradient from higher wave exposure and lower salinity on the left, to little exposed assemblages and highly saline waters on the right. Other descriptors related to natural environmental stress (range of salinity and temperature) were also related to the positive part of the first axis. The second axis was related with depth and nutrient content in the water column, with greater depth and phosphate in the positive part and nitrate in the negative part. This axis explained only $18 \%$ of the total variance.

According to this, samples were distributed along a gradient from the Mediterranean assemblages on the left to the lagoon assemblages on the right. In the lagoon part, samples corresponding to El Estacio and to El Ciervo island were well differentiated. Both in the Mediterranean and lagoon samples, two gradients corresponding to the two axes were well defined within each locality, with deeper assemblages in the upper zone and shallower (and environmentally more stressed) assemblages on the right (Fig. 5a).

Thus, the macrophytobenthic species correlated with the positive portion of axis 1 are typical lagoon species such us Cladophora albida, Anotrichium tenue, Valonia aegagropila, Ulva clathrata and Liebmannia leveillei. The negative part of axis 1 would be determined by those species which do not inhabit the lagoon. The other species, located in the centre of the plot, can be considered intermediate relative to their salinity and temperature preferences. The second axis appears to be related to a gradient of decreasing depth and increasing environmental stress. Its negative part was determined by Ulva compressa, Ulva clathrata, Scytosiphon lomentaria, Liebmannia leveillei, Polysiphonia subulata and Anotrichium tenue. The positive part was determined by the phanerogams Posidonia oceanica and Cymodocea nodosa, in Cabo de Palos and El Ciervo island, respectively, and the algae Cystoseira compressa, Cystoseira foeniculace a f. tenuiramosa, Chondrophycus tenerrimus, Dictyota linearis, Taonia atomaria, Palmophyllum crassum and Codium bursa, in both sites (Fig. 5b).

\subsection{Spatio-temporal variation in macrophytobenthic assemblage structure} 3.5.1. Changes in biomass

The seasonal variation in vegetation composition and structure of the assemblages and in the biomass of individual species showed a different pattern, depending on the 
assemblage and locality (Fig. 7 and 8). The two-way analysis of variance performed considering the factors Season and Local_Assemblage found significant differences between local assemblages but did not show significant differences in biomass between seasons (Table 5). However, the three-way analysis performed for photophilous assemblages on rock, which were the only ones present in the three localities and so permitted a well balanced analysis, showed significant differences between Localities $(p<0.001)$, Assemblages $(p<0.001)$ and the interaction Season*Locality $(p<0.05)$ (Table 6 ) but, again, no differences were found between seasons either for the interaction Season*Assemblage or Season*Locality*Assemblage. This suggests that the assemblages show low seasonal changes in their total biomass and that these small changes are dependent on differences in the environmental conditions in the three localities that condition the biomass assemblage (Fig. 7 a-c). On the other hand, the Caulerpa prolifera meadow showed significant differences in biomass between localities but they showed the same seasonal pattern (Table 7, Fig. 7d).

The behaviour of individual species was heterogeneous (Fig. 8). Of the 36 species analysed, 15 showed seasonal changes at some significant level $(p<0.05)$ (Table 8). Cladostephus spongiosus, Cymodocea nodosa, Halopteris filicina and Peyssonnelia squamaria showed significant differences in biomass between assemblages but not significant seasonal variations (at $p<0.05$ ).

Ceramium ciliatum and Ceramium tenerrimum (G. Martens) Okamura only showed significant temporal patterns, but no differences were found between assemblages. Cystoseira compressa, Cystoseira foeniculacea f. tenuiramosa and Stypocaulon scoparium showed significant differences in biomass between assemblages and between seasons, but the temporal patterns were the same in all the communities and localities in which they were present.

On the other hand, although Acetabularia acetabulum, Caulerpa prolifera, Chondrophycus tenerrimus, Dictyota fasciola, Dictyota linearis, Haliptilon virgatum, Jania rubens, Jania rubens var corniculata, Padina pavonica and Ulva intestinalis also showed significant seasonal variations, the interaction Season*Local_Assemblage was also significant, indicating that those patterns were different in each local assemblage.

Cladophora vagabunda, Cladophoropsis modonensis, Corallina elongata, Dasya corymbifera, Laurencia obtusa, Liagora viscida, Lyngbia sordida and Valonia aegagropila showed no spatial or temporal variations at the studied scales.

\subsubsection{Changes in community structure}

The spatial and seasonal variability in species richness and diversity were higher than in total biomass. Species richness and diversity showed strongly significant differences between local_assemblages, with the Cabo de Palos midlittoral and the El Ciervo island infralittoral photophilous communities being the richest and most diverse and the Caulerpa prolifera meadows, both at El Estacio and El Ciervo island, the least rich and 
least diverse. However, seasonal variations showed different patterns for species richness and for diversity. Species richness showed significant seasonal variations at $p<0.05$ level but the Tukey test identified no significant groups. In the case of diversity, seasonal variations were highly significant $(p<0.001)$, with the highest diversity in spring and summer and lowest in winter and autum. However, the fact that the interaction Season* Local_Assemblage was also significant $(p<0.001)$ indicates that seasonal patterns in diversity were not the same at all the Local_assemblages (Fig. 7i-1).

The ANOVA three-way analysis performed on photophilous assemblages on rock gave similar results (Table 6). In the case of species richness, differences were significant for Season $(p<0.005)$ and for Locality $(p<0.001)$, and for the interactions between Locality*Assemblage $(p<0.001)$. In the case of diversity, differences were also significant for Season $(p<0.001)$ and for Locality $(p<0.001)$, and the interactions between Locality*Assemblage $(p<0.001)$ and Season* Locality* Assemblage $(p<0.005)$. In both cases, the highest values were reached at Cabo de Palos and the lowest at El Estacio.

In the Caulerpa prolifera meadow (Table 7), differences were only significant for diversity in the case of the factor Locality $(\mathrm{IC}>\mathrm{EE}, p<0.05)$ and for the interaction Season x Locality $(p<0.05)$.

\section{Discussion and conclusions}

Lagoon macrophyte benthic assemblages are diverse, heterogeneous and well characterized according to the hydrological conditions pertaining to a particular depth range or substrate or in given wave exposure conditions. This work contributes to solving the long-standing discrepancies, whether coastal lagoons show similar vertical zonation patterns to those observed in open coastal areas (as assumed by Mars, 1966; Bianchi, 1988a, 1988b; Occhipinti et al., 1988) or whether, on the contrary, the lagoon environment constitutes a uniform system, controlled by extreme physico-chemical conditions which disguise any small scale pattern. According to our results, the eurihaline and eurithermal biocenosis proposed by Pérès and Picard (1964) and Augier (1982) to define coastal lagoon assemblages applies to just one particular assemblage characteristic from lagoon soft (muddy) bottoms in more or less confined areas.

Our results showed that both marine and lagoon assemblages are clearly differentiated as regards species composition, and that different lagoon assemblages are similarly well differentiated according to vertical and horizontal zonation patterns. Inside the lagoon, the macrophyte assemblages showed the same vertical zonation patterns and patch distribution (according the nature of the substrata and physico-chemical environmental conditions) as the equivalent assemblages in open coastal areas.

However, the boundaries between vertical zonation levels were narrower in the inner lagoon and some species that are characteristic from the midlittoral in open coastal 
zones were common in the infralittoral part in the lagoon. While the midlittoral and infralittoral photophilous assemblages on rock shared $34.0 \%$ and $33.3 \%$ of the algae species at Cabo de Palos and El Estacio, respectively, at El Ciervo island these two assemblages shared up to $79.2 \%$ of the species. This would explain the structural similarities and the proximity in the ordination diagrams observed between midlittoral photophilous assemblages on rock from Cabo de Palos and the infralittoral photophilous assemblage in El Ciervo island.

Nineteen species $(27.5 \%)$ are shared by the lagoon and open coast marine assemblages studied in this work and most of the others characterize (Pérès and Picard, 1964; Augier, 1982) or are common in the different communities in the south-western Mediterranean (Pérez-Ruzafa, I. and Honrubia, 1984; Pérez-Ruzafa et al., 1991; FloresMoya et al., 1995a, 1995b; Conde et al., 1996).

The main differences observed between assemblages are due to a few exclusive species from distinct levels and environments and to differences in the dominance relationships. In the lagoon environment, especially in the most confined areas, the term "paralic" (sensu Frisoni et al., 1983; Guelorget et al., 1983; Guelorget and Perthuisot, 1983, 1992) referring to typically lagoon species could still be useful.

Despite the confinement theory (Guelorget et al., 1983; Guelorget and Perthuisot, 1983, 1992), according to which there would be a decreasing gradient in species richness from the inlets communicating with the open sea to the inner parts (more confined) of the lagoon, the assemblages at El Estacio showed the lowest number of species and lowest diversity. In fact, El Estacio only shared 13 species with the open coastal assemblages. Pérez-Ruzafa (1989) and Pérez-Ruzafa and Marcos (1992, 1993), on the basis of evidence from faunal assemblage gradients in the Mar Menor, reformulated the confinement theory in different terms so that, instead of the recycling of "vitamins or vital elements" and the influence of seawater, the main factor explaining the structure of lagoon assemblages in a confinement gradient would be the rates of colonization by Mediterranean species. So, for the fauna, the species composition at each lagoon site will be the result of equilibria in the context of interspecific competition between sea and lagoon species, taking into account that lower competition coefficients of Mediterranean species in the lagoon environment or the partial or complete lack of reproduction inside the lagoon could be compensated by high immigration rates of juveniles or adults from outer habitats. However, this mechanism does not seem to be valid for vegetation. It could apply to some vegetal species - for example, some mats of Posidonia oceanica have occasionally been observed in the inlet-influenced areas of the Mar Menor and the invasive algae Caulerpa prolifera were seen to progressively colonize the lagoon from the less confined areas to the inner parts of the lagoon (PérezRuzafa et al., 1989, 2005b) and is now colonizing rocky substrates (unpublished data). However, according to the results of this work, this does not seem to be applicable to most macrophyte species and the dispersion and colonization mechanisms of the vegetation need to be analysed in greater depth. 
El Estacio assemblages can be considered distinct assemblages (well differentiated and characterized by some exclusive species). The site is not an ecotone between open coastal and lagoon communities, but a lagoon location with environmental instability tolerated only by some species. This would explain its lower species richness and diversity. This instability could not be related to the maximum and minimum temperature or salinity, or to the medium and long term variation in these parameters, but with the short term (hours to days) scale determined by the changes in direction of the current at the inlet (with a mean periodicity of 6 hours) (Arevalo, 1988) and the alternating influence of Mediterranean and lagoon conditions.

The different assemblages described in this work could be considered as real biocenoses sensu Margalef (1974), as communities that do not depend on organisms external to themselves and in which the internal relationships are always stronger than the interchanges with adjacent ones. In the case of both the vertical and horizontal zonation of macrophyte assemblages, the different communities can not be understood without the concepts of continuum and nodum, sensu Boudouresque $(1970,1971)$, and of biocenosis (see Ballesteros, 1992 for a general review).

Many characteristic species showed significant differences in biomass for the factor Local_assemblage and for the interaction Locality $\mathrm{x}$ Assemblage in the photophilous rocky assemblages. This would confirm the differences obtained in the ordination analyses. However, precisely because of the differences existing between the three localities, a more complete bionomic study would need to replicate each one of the three environmental situations.

As regards the total assemblages, biomass is higher in Cabo de Palos than in the lagoon and in the infralittoral assemblages than in the midlittoral. No significant differences were found between the same assemblage in the two localities inside the lagoon except for the Caulerpa prolifera meadow, which showed higher biomass in El Estacio than in El Ciervo island. De Biasi et al. (2003) also found that macroalgae were generally more abundant in the outer part of the Orbetello lagoon but did not consider vertical zonation patterns or the influence of depth in their study. These authors rejected the theory of "confinement" to describe spatial pattern in assemblages in every lagoon because of the spatial variability that they found over scales of tens to hundreds of metres. However, as they did not consider the direction of currents and did not analyze any environmental variable, such a rejection can not be supported.

Substrate type, nutrient concentration and the influence of sea vs fresh water are among the main factors affecting the species composition and abundance in macrophyte assemblages in coastal lagoons (Pasqualini et al., 2006). According to our results, two additional factors seem to overlap in determining macrophyte biomass: open sea $v s$. lagoon environment, and infralittoral $v s$. midlittoral. Both could be defined as environmental stress gradients operating at the same time on two different spatial 
scales: from hundreds of metres to kilometres in the horizontal plane, thus defining the degree of isolation from the sea, and from centimetres to metres in the vertical zonation. In this way, infralittoral photophilous assemblages and Posidonia meadows at Cabo de Palos showed the highest biomass followed by midlittoral photophilous assemblages in the same locality, while the latter show the same biomass as the infralittoral assemblages of the lagoon. Finally, midlittoral lagoon assemblages show the lowest biomass.

This parallel effect of confinement and vertical zonation also occurs in species composition so that, as stated above, some species that are characteristic of the midlittoral in open coastal zones, are common in the infralittoral in the lagoon. There are also structural similarities, as shown by the proximity in the ordination diagrams, between midlittoral photophilous assemblages on rock from Cabo de Palos and the infralittoral photophilous assemblage in El Ciervo island.

In addition, many species showed seasonal variations, depending on the locality. Seasonal changes in algal abundance are common in the Mediterranean where algal abundance drops off sharply in summer (Coma et al., 2000). However, as with light and nutrients, the main factors determining the production of algal communities, display different temporal dynamics. The dynamics of algae from different groups and depths will be conditioned by the seasonal cycle of the main limiting factor affecting them. In shallow assemblages that reach a production peak in spring, nutrients are usually the main limiting factors, while light availability becomes the limiting factor at increasing depth so that deeper assemblages reach their maximum production in summer (Ballesteros, 1991). In the study area, light, water temperature and salinity showed similar seasonal patterns in the three localities, while nutrient concentration in the water column showed different dynamics. Thus, the difficulty of finding significant seasonal differences in biomass may be related to the fact that each factor acts in a different way on the biomass each season. Furthermore, many of the observed changes in vegetation would be due to the natural seasonal life cycle of the species present. There are perennial species that are present in a given season in the form of erect thalli and in other periods as basal parts or encrusting thalli (e.g. Cystoseira spp., Chondrophycus tenerrimus) and there are annual species which have a life cycle lasting only a restricted period of the year or species with several generations in a year (Ulva spp., Cladophora spp.) (Feldmann, 1951).

Maximum development of the assemblages on rock was observed in summer and autumn in Cabo de Palos but in spring at El Ciervo island, a lag that could be related with the negative effect of extreme summer conditions in the inner lagoon. A spring maximum in macrophyte biomass has been observed in other Mediterranean lagoons (De Biasi et al., 2003).

The pelagic primary productivity cycle shows different patterns in different parts in the Mar Menor (Pérez-Ruzafa et al., 2005a). In the internal areas of the lagoon, including El 
Ciervo island, the concentrations of chlorophyll $a$ in the water column were also maximal in spring and minimal in winter. At El Estacio, and in the central part of the lagoon, under Mediterranean influence, the maximum was reached in summer. This pattern seems to be similar to that observed in infralittoral photophilous assemblages.

Of particular note were the differences in biomass observed between the summer of 1995 and 1996, particularly in the Cabo de Palos assemblages, where nearly all the dominant species decreased substantially during the second year. Only Haliptilon virgatum, in the infralittoral photophilous community, showed the inverse pattern.

Between 1995 and 1996 the total biomass dropped by one third in the midlittoral photophilous community, by two thirds in the infralittoral photophilous assemblage and by half in the sciaphilous assemblage. However, the Posidonia oceanica assemblage underwent a much smaller decrease.

Despite the interannual decrease in biomass observed in the open coast assemblages, the lagoon assemblages at El Estacio and El Ciervo island did not show the same general pattern. However, the behaviour of some species, such as Cladophora albida and Padina pavonica, whose biomass decreased, or the opposite response shown by Chondrophycus tenerrimus and Cystoseira compressa, whose biomass increased, suggests that the observed pattern was not a consequence of a local impact but of a general process affecting the whole area. Such environmental stress would not affect the species already adapted to extreme environments (Caulerpa prolifera, Chondrophycus tenerrimus or Cystoseira compressa at El Ciervo island) and would mainly have a negative effect on the species in more stable environments.

These differences also suggest that supra-annual temporal scales of variability are important in macrophyte lagoon assemblage dynamics. In this work, Caulerpa prolifera was present as a frequent and characteristic species on the infralittoral rocky bottoms of both El Estacio and El Ciervo island. This species is characteristic of muddy substrata and invaded the Mar Menor lagoon in the early 1970's after widening of El Estacio inlet (Pérez-Ruzafa et al., 1989, 1991). The colonization of the infralittoral photophilous assemblages on rock by this invasive algae, which is characteristic of muddy bottoms, constitutes a progressive process (Pérez-Ruzafa et al., 1991) which is endangering the biological diversity of the Mar Menor hard substrata lagoon assemblages, in the same way that it has already affected the communities on sandy bottoms (Pérez-Ruzafa et al., 2006). Accordingly, long term studies will be necessary to analyze the inter-annual patterns of variation.

In conclusion, macrophytic benthic assemblages in the Mar Menor lagoon are not homogeneous and it is possible to identify distinct assemblages with the same vertical zonation that can be found in all marine communities, but characterized by well defined groups of species, according to their isolation from the open sea and the type of 
substratum. This implies that when applying the EU Water Framework Directive a lagoon should not be considered as a homogeneous unit but as a mosaic of assemblages.

However, before the structure and composition of the assemblages described for the Mar Menor can be generalised and applied to other lagoon communities in the Mediterranean, more extensive studies of other lagoons are necessary.

\section{References}

Alongi, D.M. 1998. Coastal ecosystem processes. Boca Raton: CRC Press.

Anonymous 1959. Final resolution. The Venice System for the Classification of Marine Waters according to salinity. Arch. Oceanogr. Limnol. 11, suppl., 243-245.

Arévalo, L. 1988. El Mar Menor como sistema forzado por el Mediterráneo. Control hidráulico y agentes fuerza. Bol. Inst. Esp. Oceanogr., 5, 63.

Augier, H. 1982. Inventory and classification of marine benthic biocenoses of the Mediterranean. Council of Europe, European Committee for the Conservation of Nature and Natural Resource. Nature and Environment Series, 25, Strasbourg. Austoni, M., Giordani, G., Viaroli, P., and Zaldívar, J.M. 2007. Application of specific exergy to macrophytes as an integrated index of environmental quality for coastal lagoons. Ecological Indicators, 7, 229-238.

Bachelet, G., de Montaudouin, X., Auby, I., and Labourg, P.J. 2000. Seasonal changes in macrophyte and macrozoobenthos assemblages in three coastal lagoons under varying degrees of eutrophication. Ices J. Mar. Sci., 57 (5), 1495-1506.

Ballesteros, E. 1991. Structure and dynamics of North-Western Mediterranean phytobenthic communities: a conceptual model. Oecol. Aquat., 10, 223-242.

Ballesteros, E. 1992. Els vegetals y la zonació litoral: especies, comunitats y factors que influeixen en la seva distribució (pp. 1-616). Barcelona: Arxius de la seccions de Ciènces, Institut d'Estudis Catalans.

Ballesteros, E. 1993. Species composition and structure of a photophilic algal community dominated by Halopteris scoparia (L.) Sauvageau from the NorthWestern Mediterranean. Collect. Bot. Barcelona, 22, 5-24.

Ballesteros, E., Torras, X., Pinedo, S., García, M., Mangialajo, L., and de Torres, M. 2007. A new methodology base on littoral community cartography dominated by macroalgae for the implementation of the European Water Framework Directive. Mar. Pollut. Bull., 55, 172-180.

Barnes, R.S.K. 1980. Coastal lagoons. Cambridge Studies in Modern Biology 1. Cambridge: Cambridge University Press.

Bianchi, C.N. 1988a. Caratterizzazione bionomica delle lagune costiere italiane. Acqua and Aria, 4, 15-20.

Bianchi, C.N. 1988b. Tipologia ecologica delle lagune costiere italiane. In: Carrada G.C., Cicogna F., Fresi E. (Eds.). Le lagune costiere: ricerca e gestione. CLEM, Massa Lábrense, Nápoles, 57-66 pp.

Bouderesque, C.F. 1970. Reserches sur les concepts de biocenose et de continuum au neveau des peuplements benthiques sciaphiles. Vie Milieu, 21 (1-B), 103-136.

Bouderesque, C.F. 1971. Contribution à l'étude phytosociologique des peuplementes algaux des côtes varoises. Vegetatio, 22(1-3), 83-184. 
Bremner, J.M. 1965. Total Nitrogen. In: Black, C.A. (Ed.). Methods of soil analysis. Part 2' Chemical and Microbiological Properties. American Society of Agronomy, Inc., Wiscosin, 1149-1400 pp.

Buchanan, J.B. 1984. Sediment analysis. In: Holme, N.A., McIntyre, A.D. (Eds.). Methods for the study of marine benthos. Blackwell, Oxford, 41-65 pp.

Cecere, E., Cormaci, M., Furnari, G., Tursi, A., and Caciorgna, O. 1988. Phytocenoses in the Mar Piccolo in Taranto (Ionian Sea, southern Italy): mesolittoral level and infralittoral fringe. Rapp. Comm. int. Mer Médit., 31, 3.

Cecere E., Cormaci M., and Furnari G. 1991. The marine algae of Mar Piccolo, Taranto (southern Italy): a re-assessment. Botanica Marina, 34, 221-227.

Cecere E., Saracino O.D., Fanelli M., and Petrocelli A. 1992. Presence of a drifting algal bed in the Mar Piccolo basin, Taranto (Ionian Sea, Southern Italy). Journal of Applied Phycology, 4, 323-327.

Chassany de Casabianca, M.L. 1979. Dynamique pluriannuelle des macrophytes en milieu lagunaire. Rapp. Comm. int. Mer Médit. 25/26, 3, 175-176.

Chassany de Casabianca, M.L. 1980. Évolution biocénotique du bord des étangs en Corse. Tethys, 9 (3), 299-308.

Cinelli, F., Fresi, E., Idato, E., and Mazzella, L. 1977. L'aire minima du phytobenthos dans un peuplement a Cystoseira mediterranea de l'ile d'Ischia (Golfe de Naples). Rapp. Comm. Int. Mer Médit., 24 (4), 113-115.

Clarke, K.R., and Green, R.H. 1988. Statistical design and analysis for a biological effects study. Mar. Ecol. Prog. Ser., 46, 213-226.

Clarke, K.R., and Warwick, R.M. 2001. Change in Marine Communities. An approach to statistical analysis and interpretation. Plymouth: Primer-E Ltd.

Coma, R., Ribes, M., Gili, J.M., and Zabala, M. 2000. Seasonality in coastal benthic ecosystems. Tree, 15(11), 448-453.

Conde, F., Flores-Moya, A., Soto, J., Altamirano, M., and Sanchez, A. 1996. Check-list of Andalusian (S. Spain) seaweeds. III. Rhodophyceae. Acta Bot. Malacitana, 21, 733.

Cox, G.W. 1981. Laboratory manual of general ecology. Dubuque, Iowa: William C. Brown Company Publishers.

Curiel, D., Rismondo, A., Bellemo, G., and Marzocchi, M. 2004. Macroalgal biomass and species variations in the Lagoon of Venice (Northern Adriatic Sea, Italy): 19811998. Sci. Mar., 68 (1), 57-67.

Day, P.R., Field, J.G., and Montgomery, M.P. 1971. The use of numerical methods to determine the distribution of the benthic fauna across the continental shelf of north Caroline. J. Anim. Ecol., 40, 93-125.

De Biasi, A.M., Benedetti-Cecchi, L., Pacciardi, L., Maggi, E., Vaselli, S., and Bertocci, I. 2003. Spatial heterogeneity in the distribution of plants and benthic invertebrates in the lagoon of Orbetello (Italy). Oceanol. Acta, 26 (1), 39-46.

Duchaufour, P. 1975. Manual de edafología. Barcelona: Toray-Masson.

European Union 2000. Directive 2000/60/EC of the European Parliament and of the Council of 23 October 2000 establishing a framework for Community action in the field of water policy. Official Journal, L 327.

Feldmann, J. 1951. Ecology of marine algae. In: Smith, G.M. (Ed.). Manual of Phycology - an Introduction to the Algae and their Biology. A New Series of Plant Science Books, vol. 27. , The Chronica Botanica Co., Waltham, Massachussets, 313-334 pp. 
Flores-Moya, A., Soto, J., Sanchez, A., Altamirano, M., Reyes, G., and Conde, F. 1995a. Check-list of Andalusian (S. Spain) seaweeds. I. Phaeophyceae. Acta Bot. Malacitana, 20, 5-18.

Flores-Moya, A., Soto, J., Sanchez, A., Altamirano, M., Reyes, G., and Conde, F. 1995b. Check-list of Andalusian (S. Spain) seaweeds. II. Chlorophyceae. Acta Bot. Malacitana, 20, 19-26.

Frisoni, G.F., Guelorget, O., Ximenes, M.C., and Perthuisot, J.P. 1983. Etude ecologique de trois lagunes de la plaine orientale corse (Biguglia, Diana, Urbino): expressiones biologiques qualitatives et quantitatives du confinement. Journal de recherche oceanographique, 8 (1), 57-80.

Guelorget, O., and Perthuisot, J.P. 1983. Le domaine paralique. Expressions géologiques, biologiques et économiques du confinement. Travaux du laboratoire de géologie, 16, 1-136.

Guelorget, O., and Perthuisot, J.P. 1992. Paralic ecosystems. Biological organization and functioning. Vie Milieu, 42 (2), 215-251.

Guelorget, O., Frisoni, G.F., and Perthuisot, J.P. 1983. Zonation biologique des milieux lagunaires: definition d'une echelle de confinement dans le domaine paralique méditerranéen. Journal de recherche oceanographique, 8(1), 15-35.

Guiry, M.D., and Guiry, G.M. 2007. AlgaeBase version 4.2. World-wide electronic publication, National University of Ireland, Galway. http://www.algaebase.org; searched on 02 February 2007.

Jongman, R.H.G., ter Braak, C.J.F., and van Tongeren, O.R.F. 1987. Data analysis in community and landscape ecology. Wageningen: PUDOC.

Keddy, P.A. 1983. Quantifying a within-lake gradient of wave energy in Gillfillan Lake, Nova Scotia. Can. J. Bot., 62, 301-309.

Kjerfve, B. (Ed.). 1994. Coastal lagoon processes. Elsevier Oceanography series.

Lin, H.J., and Hung, J.J. 2004. Factors affecting macroalgal distribution in a eutrophic tropical lagoon in Taiwan. Mar. Biol., 144, 653-664.

Lovric, A.Z. 1979. Herbiers benthiques des eaux saumatres de l'Adriatique orientale. Rapp. Comm. Int. Mer Médit. 25/26, 3, 169-170.

Marcos, C. 1991. Planificación ecológica y ordenación del territorio en el litoral. PhD thesis, Universidad de Murcia.

Margalef, R. 1974. Ecología. Barcelona: Omega.

Mariani, S. 2001. Can Spatial Distribution of Ichthyofauna Describe Marine Influence on Coastal Lagoons? A Central Mediterranean Case Study. Estuar. Coast. Shelf S., doi 10.1006/ecss.2000.0746

Mars, P. 1966. Recherches sur quelques étangs du littoral méditerranéen français et sur leurs faunes malacologiques. Vie et Mileu, 20, 1-359.

Mouillot, D., Gaillard, S., Aliaume, C., Verlaque, M., Belsher, T., Troussellier, M., and Chi, T.D. 2005. Ability of taxonomic diversity indices to discriminate coastal lagoon environments based on macrophyte communities. Ecological Indicators, 5 (1), 1-17.

Nagy, C.G. 1979. Cartographie floristique dans la lagune Sinoë. Rapp. Comm. Int. Mer Médit. 25/26, 3, 179-180.

Occhipinti Ambrogi, A., Bianchi, C.N., Morri, C., and Sconfietti, R. 1988. Recherches sur la zonation verticale du macrobenthos sessile dans la lagune de Venise. Cah. Biol. Mar., 29(3), 297-311.

Parsons, T.R., Maita, L., and Lalli, C.M. 1984. A Manual of Chemical and Biological Methods for Seawater Analysis. New York: Pergamon Press. 
Pasqualini, V., Pergent-Martini, C., Fernandez, C., Ferrat, L., Tomaszewski, J.E., and Pergent, G. 2006. Wetland monitoring: aquatic plant changes in two Corsican coastal lagoons (Western Mediterranean Sea). Aquat. Conserv.: Mar. Freshw. Ecosyst., 16 (1), 43-60.

Pèrés, J.M., and Picard, J. 1964. Nourveau manuel de bionomie benthique de la Mer Mediterranee. Travaux de la station marine d'Endoume, 31 (47), 1-137.

Pérez-Ruzafa, A. 1989. Estudio ecológico y bionómico de los poblamientos bentónicos del Mar Menor (Murcia, SE de España). PhD thesis, Universidad de Murcia.

Pérez-Ruzafa, A., and Marcos, C. 1992. Colonization rates and dispersal as essential parameters in the confinement theory to explain the structure and horizontal zonation of lagoon benthic assemblages. Rapp. Comm. Int. Mer Medit., 33, 100.

Pérez-Ruzafa, A., and Marcos, C. 1993. La teoría del confinamiento como modelo para explicar la estructura y zonación horizontal de las comunidades bentónicas en las lagunas costeras. Publicaciones Especiales del Instituto Español de Oceanografía, 11, 347-358.

Pérez-Ruzafa, A., Fernández, A.I., Marcos, C., Gilabert, J., Quispe, J.I., and GarcíaCharton, J.A. 2005a. Spatial and temporal variations of hydrological conditions, nutrients and chlorophyll a in a Mediterranean coastal lagoon (Mar Menor, Spain). Hydrobiologia, 550, 11-27.

Pérez-Ruzafa, A., García-Charton, J.A., Barcala, E., and Marcos, C. 2006. Changes in benthic fish assemblages as a consequence of coastal works in a coastal lagoon: The Mar Menor (Spain, Western Mediterranean). Mar. Pollut. Bull., 53 (1-4), 107-120.

Pérez-Ruzafa, A., Gilabert. J., Gutiérrez, J.M., Fernández, A.I., Marcos, C. and Sabah, S. 2002. Evidence of a planktonic food web response to changes in nutrient input dynamics in the Mar Menor coastal lagoon, Spain. Hydrobiologia, 475/476, 359369.

Pérez-Ruzafa, A., Marcos, C., and Gilabert, J. 2005b. The ecology of the Mar Menor coastal lagoon: a fast-changing ecosystem under human pressure. In: Gönenç, I.E., Wolflin, J.P. (Eds.). Coastal Lagoons: Ecosystem Processes and Modeling for Sustainable Use and Development. CRC Press, Boca Ratón, Florida, 392-422 pp.

Pérez-Ruzafa, A., Marcos-Diego, C., and Ros, J.D. 1991. Environmental and biological changes related to recent human activities in the Mar Menor (SE of Spain). Mar. Pollut. Bull., 23, 747-751.

Pérez-Ruzafa, A., Navarro, S., Barba, A., Marcos, C., Cámara, M.A., Salas, F. and Gutierrez, J.M. 2000. Presence of pesticides throughout trophic compartments of the food web in the Mar Menor lagoon (SE Spain). Mar. Pollut. Bull., 40 (2), 140-151.

Pérez-Ruzafa, A., Quispe-Becerra, J.I,, García-Charton, J.A., and Marcos, C. 2004. Composition, structure and distribution of the ichthyoplankton in a Mediterranean coastal lagoon. J. Fish. Biol., 64 (1), 202-218.

Pérez-Ruzafa, A., Ros, J.D., Marcos, C., Ballester, R., and Pérez-Ruzafa, I. 1989. Distribution and biomass of the macrophyte beds in a hypersaline coastal lagoon (the Mar Menor, SE Spain), and its recent evolution following major environmental changes. In: Bouderesque, C.F., Meinesz, A., Fresi, E., Gravez, V. (Eds.). International Workshop on Posidonia Beds 2. GIS Posidonie, Marseille, 49-62 pp. Pérez Ruzafa, I., and Honrubia, M. 1984. Aportación al conocimiento de la flora algal bentónica de la costa murciana. III. Anales de Biología, 2 (sección especial 2), 135 146.

Petit, G. 1953. Introduction à l'étude écologique des étangs méditerranéens. Vie Milieu, 4(4), 569-604. 
1003

1004

1005

1006

1007

1008

1009

1010

1011

1012

1013

1014

1015

1016

1017

1018

1019

1020

1021

1022

1023

1024

1025

1026

Pinedo, S., García, M., Satta, M.P., de Torres, M., and Ballesteros, E. 2007. Rockyshore communities as indicators of water quality : a case study in the Northwestern Mediterranean. Mar. Pollut. Bull., 55, 126-135.

Por, F.D. 1972. Hidrobiological notes on the high-salinity waters of the Sinai Peninsula. Mar. Biol., 1, 121-131.

Ross, S.W., and Epperly, S.P. 1985. Utilization of shallow estuarine nursery areas by fishes in Pamlico Sound and adjacent tributaries, North Carolina. In: YañezArancibia, A. (Ed.). Fish community ecology in estuaries and coastal lagoons: towards ecosystem integration. DR(R) Unam Press, Mexico, 207-232 pp.

Sfriso, A. 1987. Flora and vertical distribution of macroalgae in the lagoon of Venice: a comparison with previous studies. Giornale Botanico Italiano, 121, 69-85.

Sfriso, A., and La Rocca, B. 2005. Aggiornamento sulle macroalghe presenti lungo i litorali e sui bassofondali della Laguna di Venezia. Lavori della Società Veneta di Scienze Naturali, 30, 45-56

Sfriso, A., Facca, C., and Ghetti, P.F. 2003. Temporal and spatial changes of macroalgae and phytoplankton in a Mediterranean coastal area: the Venice lagoon as a case study. Mar. Environ. Res., 56, 617-636.

Skolka, V.H., and Tiganus V. 1985. Sur le phytobenthos et le zoobenthos du lac sursale Tekirghiol. Rapp. Comm. Int. Mer Médit., 29, 4, 169-170.

Soil Conservation Service. U.S. Department of Agriculture 1973. Investigación de suelos. Métodos de laboratorio y procedimientos para recoger muestras. México: Editorial Trillas.

ter Braak, C.J.F. 1990. Update notes: CANOCO v3.10. Wageningen: Agricultural Mathematics Group.

ter Braak, C.J.F. 1997. Update notes: Canoco v. 3.15. Wageningen: Agricultural Mathematics Group DLO.

ter Braak, C.J.F., and Prentice, I.C. 1988. A theory of gradient analysis. Adv. Ecol. Res., 18, 271-317

Underwood, A.J., 1997. Experiments in ecology. Cambridge: Cambridge University Press.

UNESCO, 1981. Coastal lagoons research, present and future. UNESCO Tech. papers Mar. Sci., 33.

Wells, E., Wilkinson, M., Wood, P., and Scanlan, C. 2007. The use of macroalgal species richness and composition on intertidal rocky seashores in the assessment of ecological quality under the European Water Framework Directive. Mar. Pollut. Bull., 55, 151-161.

Wilkinson, M., Wood, P., Wells, E., and Scanlan, C. 2007. Using attached macroalgae to assess ecological status of British estuaries for the European Water Framework Directive. Mar. Pollut. Bull., 55, 136-150.

Yáñez-Arancibia, A., Lara-Domínguez, A.L., Aguirre-León, A., Díaz-Ruiz, S., Amezcua-Linares, F., Flores, D., and Chavance, P. 1985. Ecology of dominant fish populations in tropical estuaries: environmental factors regulating biological strategies and production. In: Yáñez-Arancibia, A. (Ed.). Fish Community Ecology in Estuaries and Coastal Lagoons: Towards an Ecoystem Integration. UNAM Press, Mexico, 311-365 pp.

Zouali, J. 1979. Communautes benthiques du lac de Bizerte (Tunisie septentrionale). Rapp. Comm. Int. Mer Médit. 25/26, 3, 133-134 
Figure captions

Figure 1. Geographical location of the Mar Menor lagoon and the Cabo de Palos marine protected area, and location of sampling stations.

Figure 2. Seasonal dynamic of salinity, temperature, nutrient concentration and suspended solids in the water column in the three localities studied. CP: Cape of Palos; EE: El Estacio; IC: El Ciervo Island.

Figure 3. Hierarchical clustering of presence/absence data performed on a Jaccard matrix for macrophyte mean seasonal biomass at each sampling site (assemblage) and locality. Sample codes (Locality_Assemblage_Season_Year): CP Cabo de Palos; EE El Estacio; IC El Ciervo island_MPh: midlittoral photophilous assemblages on rock; IPh: infralittoral photophilous assemblages on rock; ISc: infralittoral sciaphilous assemblages on rock; PM: Posidonia oceanica meadow; CyM: Cymodocea nodosa meadow; CaM: Caulerpa prolifera meadow_Sm Summer; A Autumn; W Winter; Sp Spring_5 1995; 6 1996. See text for the description of clusters 1 to 10.

Figure 4. MDS ordination plot based on macrophyte biomass (DW) data.

Figure 5. Ordination of samples (a) and species (b) in the representations of the first axes of the redundancy analysis (DCCA) performed on the macrophyte species matrix using environmental data as explanatory variables. Key of abbreviations for samples and species are showed in Fig. 3 and Tables 3 and 4, respectively.

Figure 6. Environmental variables explaining the species and samples distribution in the space defined by the two first axes of the redundancy analysis (DCCA) performed on the macrophyte species matrix represented in Fig. 5.

Figure 7. Seasonal variation in biomass (a-d), species richness (e-h) and Shannon diversity (i-1) in the macrophyte assemblages of the Mar Menor lagoon and Cabo de Palos. Sample codes (locality_assemblage) correspond to that Fig. 3. Error bars correspond to mean standard error.

Figure 8. Seasonal variation in biomass of dominant macrophyte species at the different assemblages and localities studied. Sample codes (locality_assemblage) correspond to that Fig. 3. Error bars correspond to mean standard error. 


\section{ACCEPTED MANUSCRIPT}

1064 Figure 1

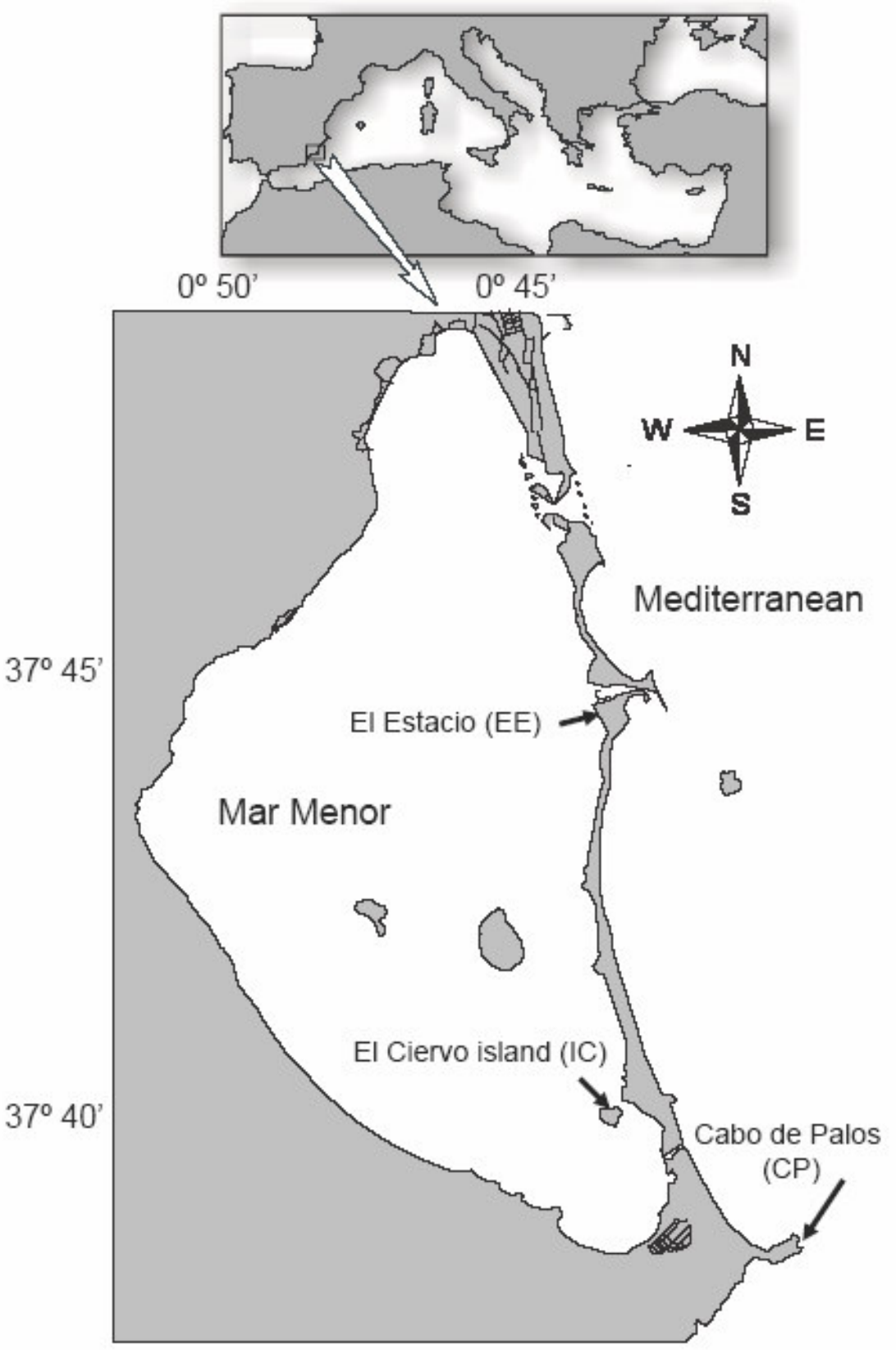

1065 


\section{ACCEPTED MANUSCRIPT}

1066 Figure 2

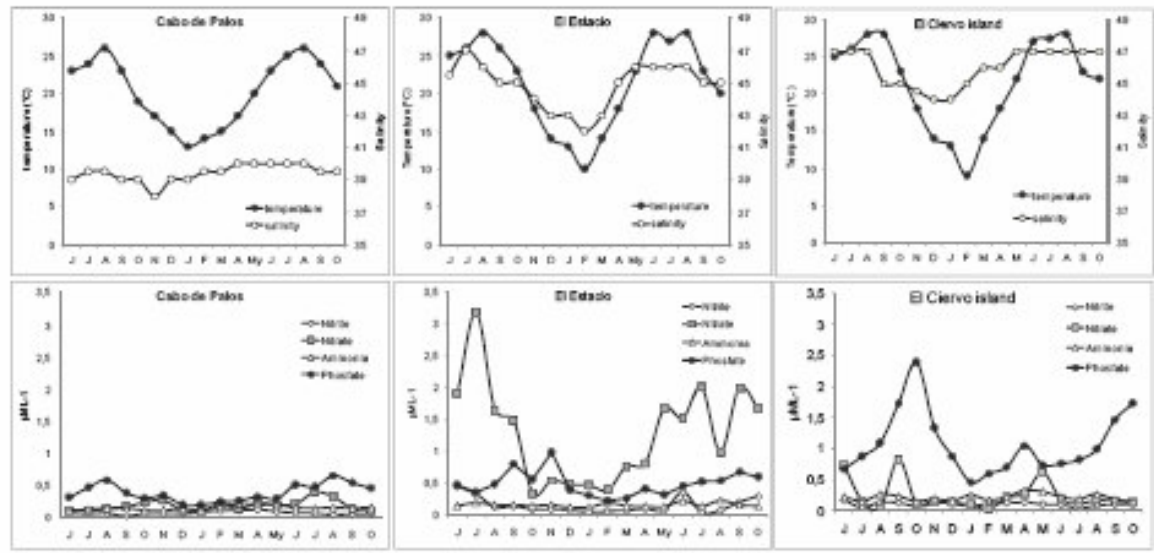

1067 


\section{ACCEPTED MANUSCRIPT}

1068 Figure 3

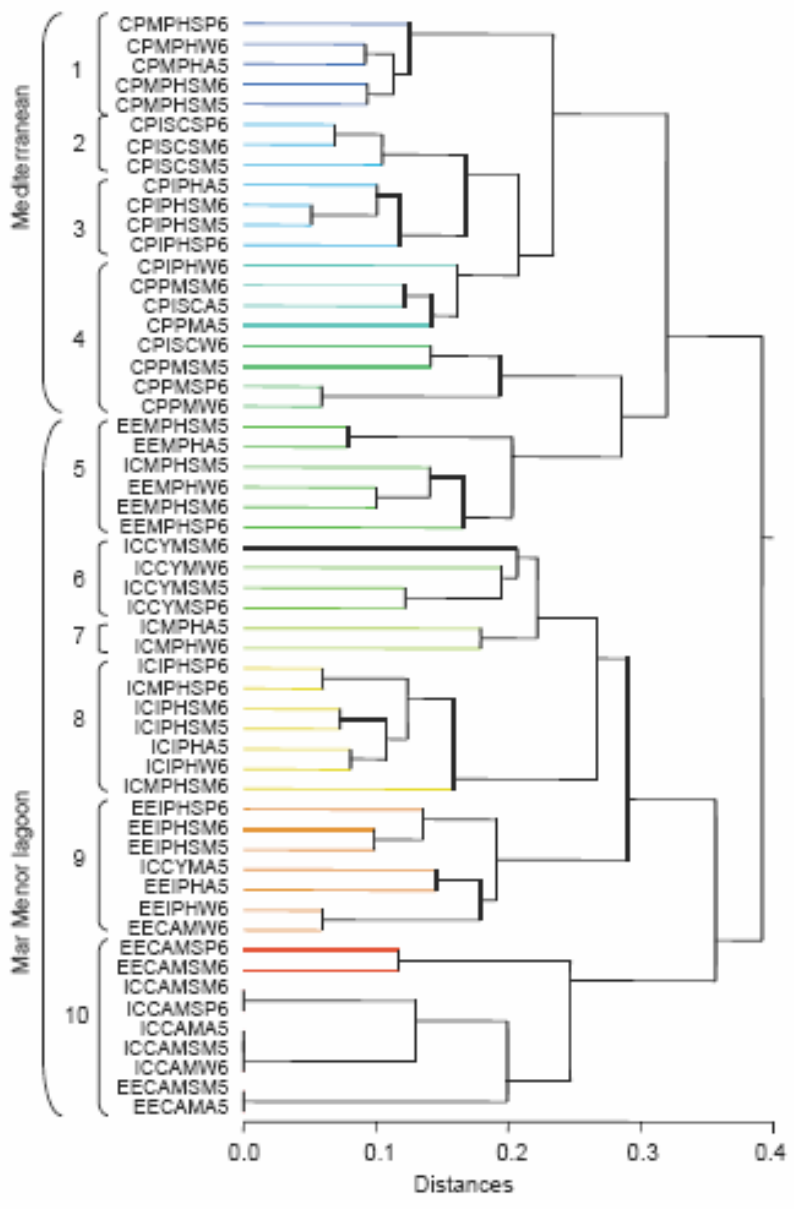

1069 


\section{ACCEPTED MANUSCRIPT}

Figure 4
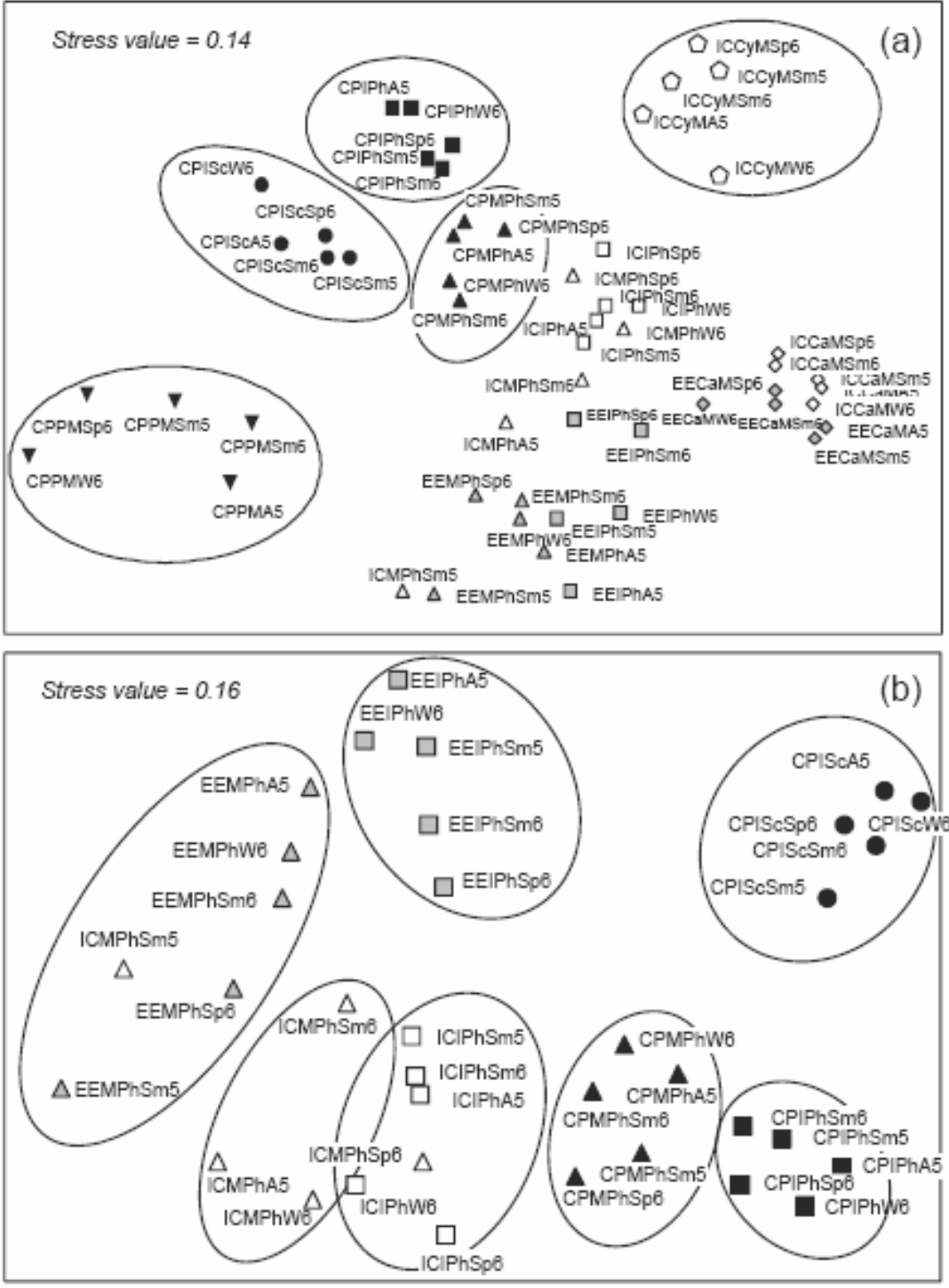

$\triangle$ MPh: mid-littoral photophilousassemblages on rock Black symbols CP: Cabo de Palos Sm5: summer 1995

$\square$ IPh: infralittoral photophilous assemblages on rock Grey symbols EE: El Estacio

A5: autumn 1985

ISc: infralittoral sciaphilous assemblages on rock

White symbols IC: El Ciervo island

$\nabla$ PM: Posidonia oceanica meadow

$\checkmark$ CyM: Cymodocea nodosa meadow

W6: winter 1986

- Call: Caulerpa prolifera meadow 


\section{ACCEPTED MANUSCRIPT}

$1072 \quad$ Figure 5
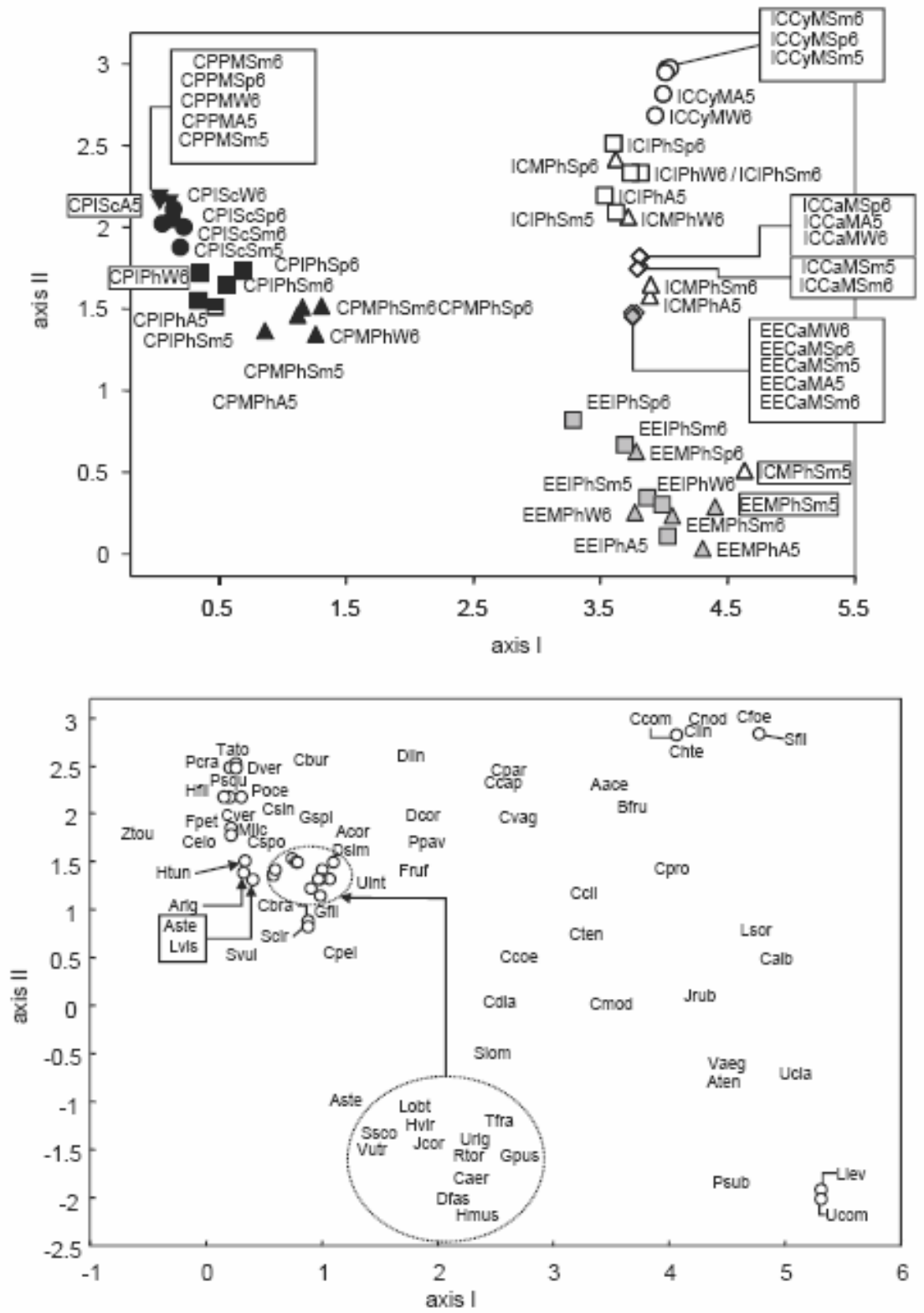

1073 


\section{ACCEPTED MANUSCRIPT}

1074 Figure 6

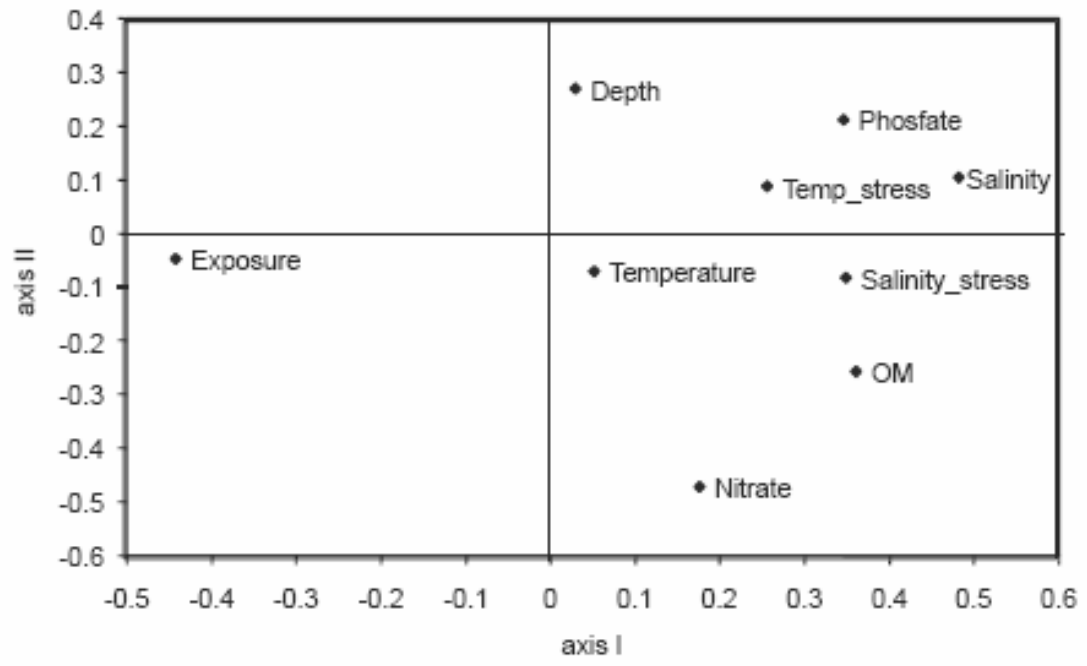

1075 


\section{ACCEPTED MANUSCRIPT}

Figure 7
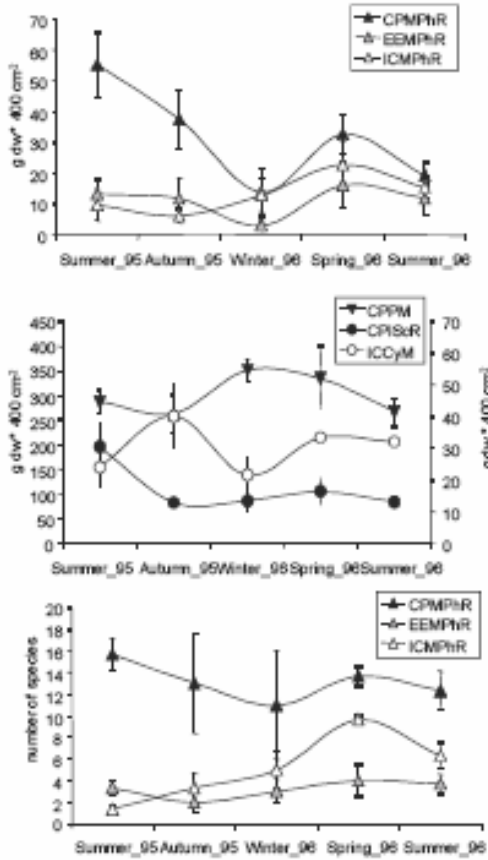

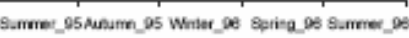
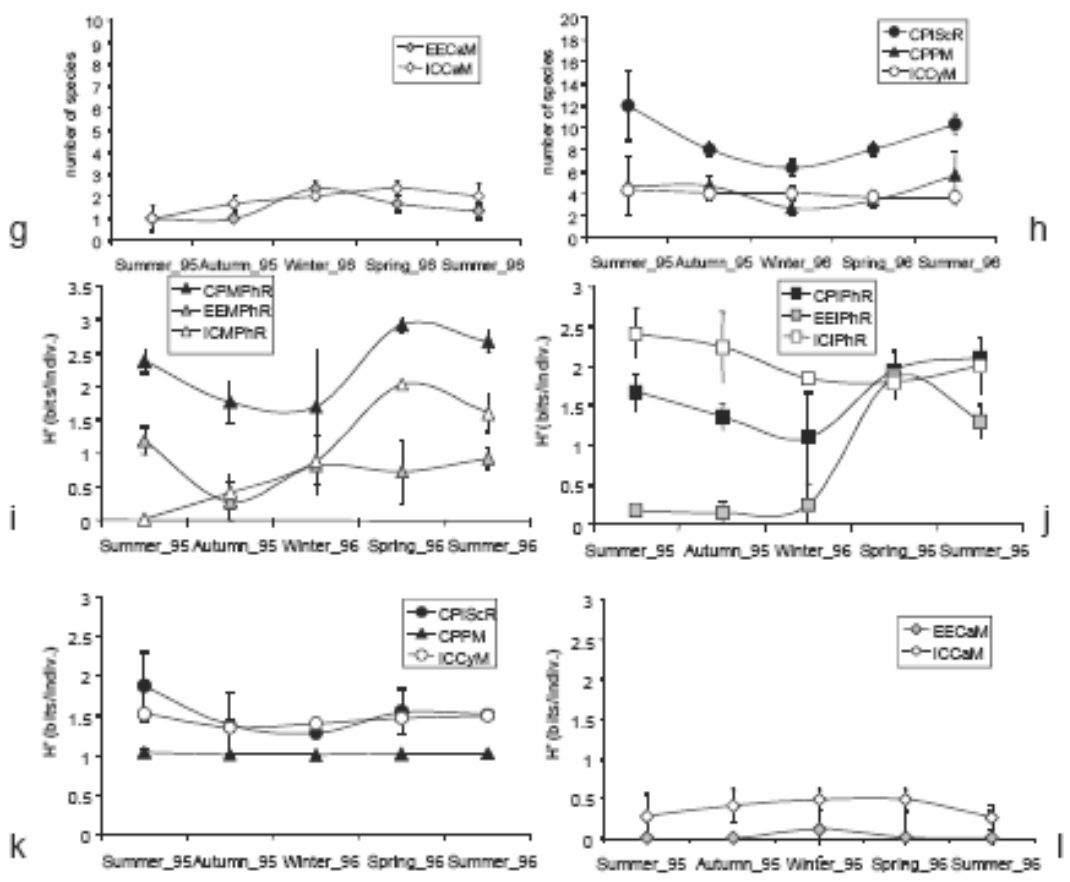


\section{ACCEPTED MANUSCRIPT}

Figure 8
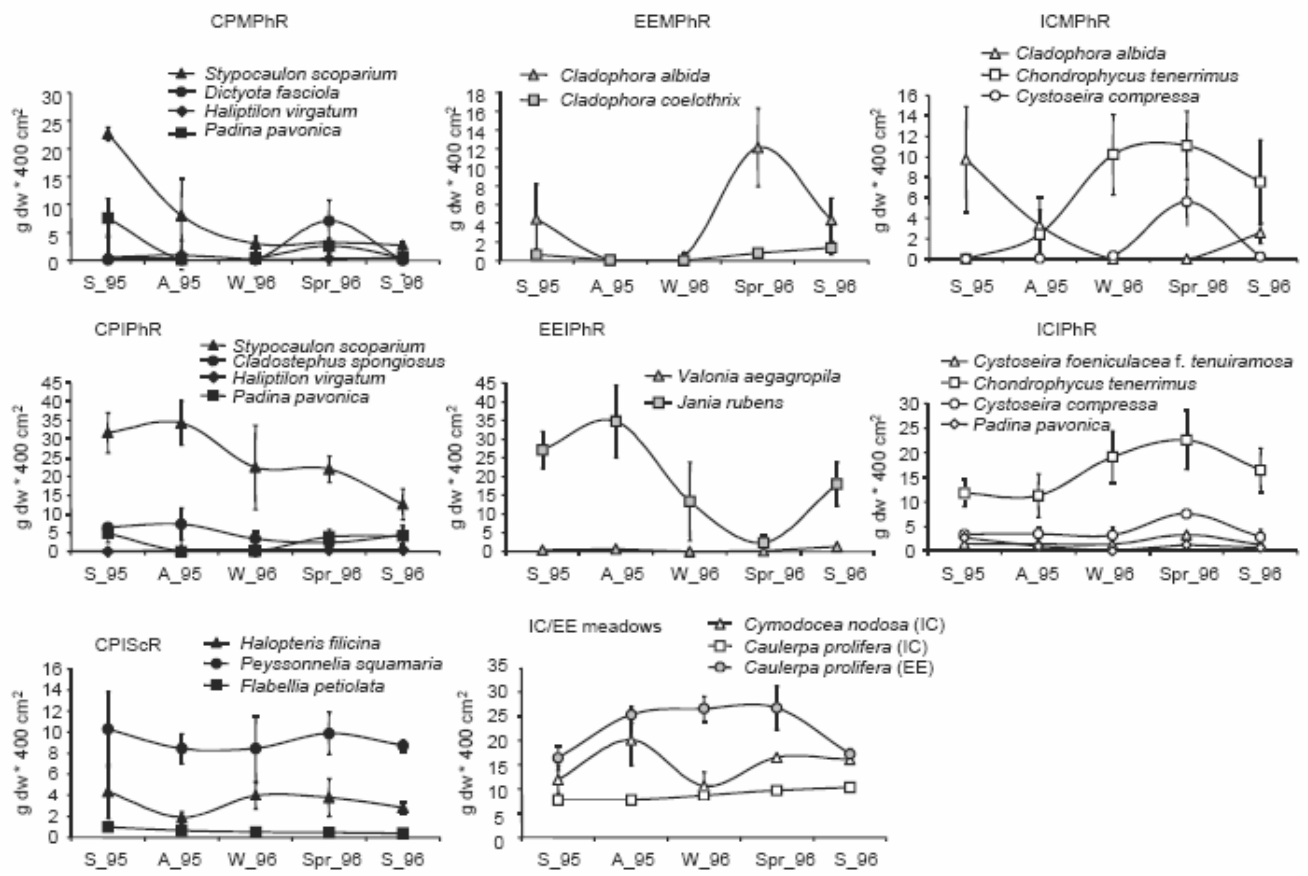

1079 
Table 1. Mean values ( \pm standard error of the mean, SEM) of environmental variables at the three localities studied. Salinity stress and Temperature stress are the difference between maximum and minimum values of these variables through the studied period.

\begin{tabular}{|c|c|c|c|c|c|c|}
\hline & \multicolumn{2}{|c|}{ Cabo de Palos } & \multicolumn{2}{|c|}{ El Ciervo island } & \multicolumn{2}{|l|}{ El Estacio } \\
\hline & mean & \pm SEM & mean & \pm SEM & mean & \pm SEM \\
\hline Wave exposure & 76518.58 & \pm 8212.63 & 1411.17 & \pm 139.51 & 3568.90 & \pm 442.81 \\
\hline \multicolumn{7}{|l|}{ water column } \\
\hline Nitrite $(\mu \mathrm{M})$ & 0.071 & \pm 0.007 & 0.100 & \pm 0.008 & 0.126 & \pm 0.025 \\
\hline Nitrate $(\mu \mathrm{M})$ & 0.196 & \pm 0.022 & 0.214 & \pm 0.056 & 1.216 & \pm 0.208 \\
\hline Ammonia $(\mu \mathrm{M})$ & 0.152 & \pm 0.008 & 0.217 & \pm 0.015 & 0.165 & \pm 0.009 \\
\hline Phosphate $(\mu \mathrm{M})$ & 0.383 & \pm 0.038 & 1.055 & \pm 0.129 & 0.488 & \pm 0.054 \\
\hline Salinity & 39.43 & \pm 0.14 & 45.90 & \pm 0.31 & 44.80 & \pm 0.38 \\
\hline Temperature $\left({ }^{\circ} \mathrm{C}\right)$ & 20.07 & \pm 1.20 & 21.23 & \pm 1.66 & 21.27 & \pm 1.61 \\
\hline $\mathrm{pH}$ & 8.10 & \pm 0.04 & 8.22 & \pm 0.06 & 8.12 & \pm 0.04 \\
\hline Suspended solids $\left(\mathrm{gL}^{-1}\right)$ & 0.074 & \pm 0.010 & 0.087 & \pm 0.00 & 0.080 & \pm 0.010 \\
\hline Salinity stress & 2 & & 3 & & 5 & \\
\hline Temperature stress $\left({ }^{\circ} \mathrm{C}\right)$ & 13 & & 19 & & 18 & \\
\hline \multicolumn{7}{|l|}{ sediment } \\
\hline Organic carbon $(\%)$ & 0.61 & \pm 0.02 & 1.49 & \pm 0.24 & 3.19 & \pm 0.34 \\
\hline Clay $(\%)(<2 \mu)$ & 7.28 & \pm 0.11 & 10.32 & \pm 1.04 & 17.55 & \pm 0.71 \\
\hline Fine Silt $(\%)(2-20 \mu)$ & 1.46 & \pm 0.18 & 2.52 & \pm 0.76 & 8.59 & \pm 1.96 \\
\hline Coarse Silt $(\%)(20-50 \mu)$ & 0.58 & \pm 0.07 & 1.00 & \pm 0.30 & 3.42 & \pm 0.78 \\
\hline Fine Sand $(\%)(50 \mu-0.2 \mathrm{~mm})$ & 4.06 & \pm 0.34 & 17.84 & \pm 1.70 & 39.74 & \pm 2.98 \\
\hline Coarse Sand $(\%)(0.2-2 \mathrm{~mm})$ & 86.62 & \pm 0.41 & 68.31 & \pm 3.49 & 30.69 & \pm 3.34 \\
\hline
\end{tabular}


Table 2. Results of mixed analysis of variance performed on environmental variables showing the effects of the factors Locality, Season and their interaction (Locality $\mathrm{x}$ Season) indicating the factors at which significant variation exists $(* * * \mathrm{P}<0.001 ; * * \mathrm{P}<0.01 ; * \mathrm{P}<0.05$ ).

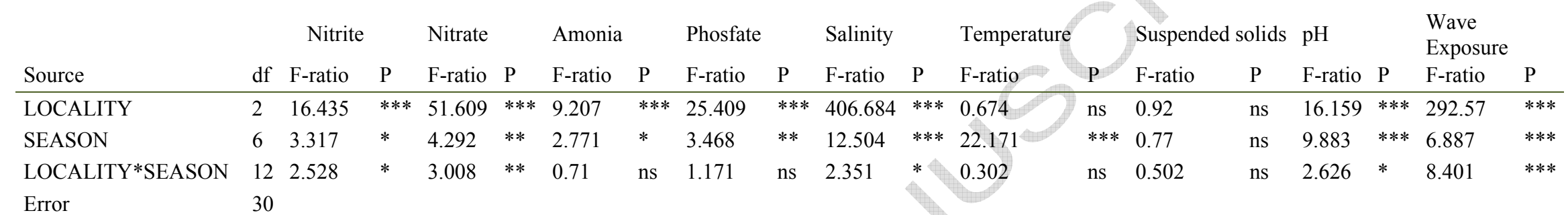


Table 3. Mean values of biomass (DW) per $400 \mathrm{~cm}^{2}$, relative dominance $(\% \mathrm{D})$ and class $(\mathrm{F})$ of frequency of occurrence of the macrophyte species sampled in this study at Cabo de Palos (CP). Abbreviations of species names used in Fig. 4b, total species richness (Sr), mean total biomass (B) and Shannon diversity (H', in bits*indiv $^{-1}$ ) at each assemblage, are also indicated (F frequent; S seasonal; O occasional). MPhR: Midlittoral Photophilous assemblage on Rock; IPhR: Infralittoral Photophilous assemblage on Rock; IScR: Infralittoral Sciaphilous assemblage on Rock; PM: Posidonia oceanica meadow.

Cyanophyta

Lyngbia sordida Gomont

Chlorophyta

Acetabularia acetabulum (Linnaeus) P.C. Silva

Anadyomene stellata (Wulfen) C. Agardh

Chaetomorpha aerea (Dillwyn) Kützing

Cladophora coelothrix Kützing

Cladophora pellucida (Hudson) Kützing

Cladophora vagabunda (Linnaeus) Hoek

Cladophoropsis modonensis (Kützing) Reinbold

Codium bursa (Linnaeus) C. Agardh

Dasycladus vermicularis (Scopoli) Krasser

Flabellia petiolata (Turra) Nizamuddin

Halimeda tuna (J. Ellis \& Solander) J.V.

Lamouroux

Rabenhorst

Ulva rigida $\mathrm{C}$ Agardh

Valonia utricularis (Roth) C. Agardh

Magnoliophyta
Posidonia oceánica (L.) Delile

Ochrophyta

Cladostephus spongiosus (Hudson) C. Agardh

Colpomenia sinuosa (Mertens ex Roth) Derbès \& Solier

Cystoseira brachycarpa var balearica (Sauvageau) Giaccone

Cystoseira compressa (Esper) Gerloff \& Nizamuddin

Dictyota fasciola (Roth) J.V. Lamouroux

Dictyota linearis (C. Agardh) Greville

Halopteris filicina (Grateloup) Kützin

Padina pavonica (Linnaeus) Thivy

Sargassum vulgare C. Agardh

Scytosiphon lomentaria (Lyngbye) Link

Sphacelaria cirrosa (Roth) C. Agardh

Stypocaulon scoparium (Linnaeus) Kützing

Taonia atomaria (Woodward) J. Agardh

Zonaria tournefortii (J.V. Lamouroux) Montagne

Rhodophyta

Alsidium corallinum C. Agardh

Amphiroa rigida J.V. Lamouroux

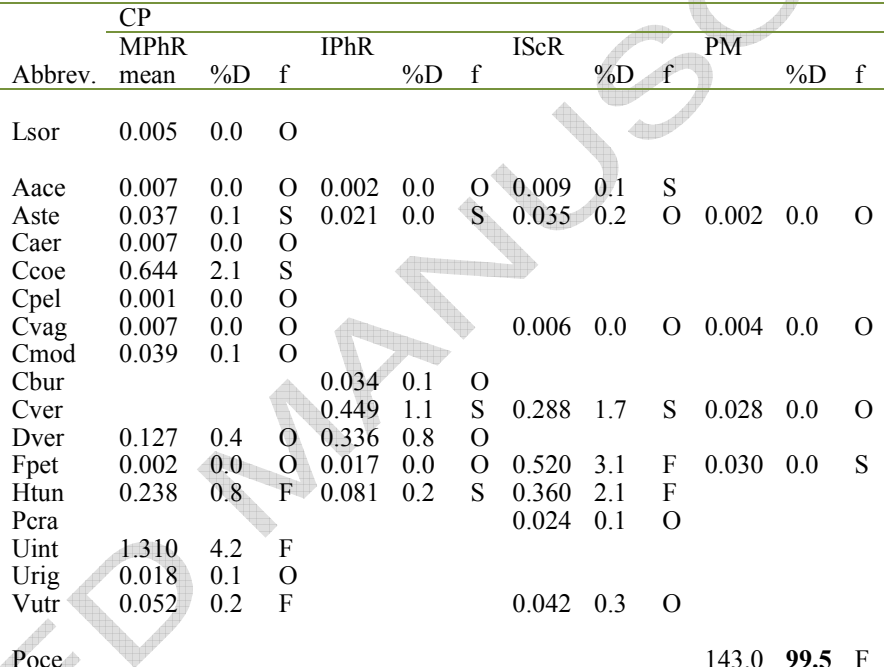

$\begin{array}{llllllllllll}0.131 & 0.4 & \mathrm{~S} & 4.835 & \mathbf{1 1 . 7} & \mathrm{F} & 0.131 & 0.8 & \mathrm{~F} & 0.055 & 0.0 & \mathrm{O}\end{array}$

$\begin{array}{lllllllll}0.047 & 0.1 & \mathrm{O} & 0.122 & 0.3 & \mathrm{O} & 0.011 & 0.1 & \mathrm{O}\end{array}$

$\begin{array}{llllll}1.119 & 3.6 & \mathrm{~F} & 0.038 & 0.1 & \mathrm{O}\end{array}$

$\begin{array}{lll}0.391 & 1.2 & \mathrm{~S} \\ 1.781 & \mathbf{5 . 7} & \end{array}$

$\begin{array}{llll}0.012 & 0.1 & \mathrm{O}\end{array}$

$\begin{array}{lllllllllllll}2.616 & \mathbf{8 . 3} & \mathrm{F} & 2.475 & \mathbf{6 . 0} & \mathrm{F} & 0.296 & 1.8 & \mathrm{~S} & 0.027 & 0.0 & \mathrm{O}\end{array}$

$\begin{array}{lll}0.093 & 0.2 & \mathrm{O}\end{array}$

$\begin{array}{lll}0.071 & 0.2 & \mathrm{O} \\ 0.009 & 0.0 & \mathrm{~S}\end{array}$

$\begin{array}{llllll}8.022 & \mathbf{2 5 . 5} & \mathrm{F} & 25.27 & \mathbf{6 0 . 9} & \mathrm{F}\end{array}$

$\begin{array}{lll}0.114 & 0.1 & \mathrm{O}\end{array}$

$\begin{array}{llllll}0.089 & 0.3 & \mathrm{O} & 0.002 & 0.0 & \mathrm{O}\end{array}$

$\begin{array}{lllllllll}0.105 & 0.3 & \mathrm{~S} & 0.405 & 1.0 & \mathrm{~S} & 0.267 & 1.6 & \mathrm{~F}\end{array}$ 
Ceramium ciliatum (J. Ellis) Ducluzeau

Ceramium diaphanum (Lightfoot) Roth

Ceramium tenerrimum (G. Martens) Okamura

Champia parvula (C. Agardh) Harvey

Chondrophycus tenerrimus (Cremades) G. Furnari, Boisset, Cormaci et Serio

Corallina elongata J. Ellis \& Solander

Dasya corymbifera J. Agardh

Digenea simplex (Wulfen) C. Agardh

Falkenbergia rufolanosa Stadium

Gelidium pusillum (Stackhouse) Le Jolis

Gelidium spinosum (S.G. Gmelin) P.C. Silva

Grateloupia filicina (J.V. Lamouroux) C. Agard h

Haliptilon virgatum (Zanardini) Garbary \& $\mathrm{H} . \mathrm{W}$. Johansen

Hypnea musciformis (Wulfen) JV. Lamouroux

Jania Rubens (Linnaeus) J.V. Lamouroux

Jania rubens var corniculata (Linnaeus) Yendo

Laurencia obtusa (Hudson) J.V. Lamouroux

Liagora viscida (Forsskål) C. Agardh

Mesophyllum lichenoides (J. Ellis) M. Lemoine

Peyssonnelia squamaria (S.G. Gmelin) Decaisne
Ccap

Celo

Celo

Fruf

Gpus

Gspi

Hvir

Hmus

Jrub

Jobt

Lobt

Mlic

Psqu

Tfra

$\mathrm{Sr}$
$\mathrm{B}$ $\begin{array}{lll}0.351 & 1.1 & \mathrm{O}\end{array}$

$\begin{array}{lll}0.016 & 0.1 & 0\end{array}$

$\begin{array}{lll}0.064 & 0.2 & \mathrm{O} \\ 0.003 & 0.0 & \mathrm{O}\end{array}$

$\begin{array}{lll}0.003 & 0.0 & 0 \\ 0.141 & 0.4 & 0\end{array}$

$\begin{array}{llll}0.145 & 0.4 & \mathrm{~F} \\ 0.555 & 1.8 & \mathrm{~F}\end{array}$

$\begin{array}{lll}0.188 & 0.6 & 0\end{array}$

$\begin{array}{lll}0.009 & 0.0 & 0 \\ 0.037 & 0.1 & 0\end{array}$

$\begin{array}{lll}0.037 & 0.1 & 0 \\ 0.047 & 0.2 & 0\end{array}$

$\begin{array}{lll}0.047 & 0.2 & 0 \\ 0.005 & 0.0 & 0\end{array}$

$\begin{array}{lll}9.254 & \mathbf{2 9 . 4} & \mathrm{F} \\ 0.065 & 0.2 & \end{array}$

$\begin{array}{lllllllllll}2.0 & \mathrm{~F} & 0.292 & 0.7 & \mathrm{~F} & 0.043 & 0.3 & \mathrm{~F} & 0.002 & 0.0 & \mathrm{O}\end{array}$

$\begin{array}{lllllll}0.174 & 0.6 & \mathrm{O} & 0.625 & 0.0 & \mathrm{O} \\ & & & \end{array}$

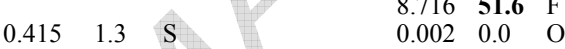

26

$\begin{array}{ll}16.90 & 143.8\end{array}$ 
Table 4. Mean values of biomass (DW) per $400 \mathrm{~cm}^{2}$, relative dominance (\% D) and class (F) of frequency of occurrence of the macrophyte species sampled in this study at the Mar Menor localities. Abbreviations of species names used in Fig. 4b, total species richness (Sr), mean total biomass (B) and Shannon diversity (H', in bits*indiv ${ }^{-1}$ ) at each assemblage, are also indicated (F frequent; S seasonal; O occasional). EE: El Estacio; IC: El Ciervo Island. MPhR: Midlittoral Photophilous assemblage on Rock; IPhR: Infralittoral Photophilous assemblage on Rock; CaM: Caulerpa prolifera meadow; CyM: Cymodocea nodosa meadow. + indicate species observed in the assemblage but not collected in the sample.

\section{Cyanophyta}

Lyngbia sordida Gomont

\section{Chlorophyta}

Acetabularia acetabulum (Linnaeus) P.C. Silva

Acetabularia calyculus J.V. Lamouroux

Caulerpa prolifera (Forsskål) J.V. Lamouroux

Chaetomorpha aerea (Dillwyn) Kützing

Chaetomorpha linum (O.F. Müller) Kützing

Cladophora albida (Nees) Kutzing

Cladophora coelothrix Kützing

Cladophora vagabunda (Linnaeus) Hoek

Cladophoropsis modonensis (Kützing) Reinbold

Ulva clathrata (Roth) C. Agardh

Ulva compressa Linnaeus

Ulva intestinalis Linnaeus

Ulva rigida C. Agardh

Valonia aegagropila $\mathrm{C}$. Agardh

Valonia utricularis (Roth) C. Agardh

Magnoliophyta

Cymodocea nodosa (Ucria) Asch.

\section{Ochrophyta}

Cystoseira compressa (Esper) Gerloff \& Nizamuddin

Cystoseira foeniculacea f. tenuiramosa (Ercegovic) A. Gómez Garreta M.C.

Barceló, M.A. Ribera \& J. Rull Lluch

Dictyota linearis (C. Agardh) Greville

Liebmannia leveillei J. Agardh

Padina pavonica (Linnaeus) Thivy

Scytosiphon lomentaria (Lyngbye) Link

Sphacelaria tribuloides Meneghini

\section{Rhodophyta}

Alsidium corallinum C. Agard

Anotrichium tenue (C. Agardh) Nägel

Boergeseniella fruticulosa (Wulfen) Kyli

Ceramium ciliatum (J. Ellis) Ducluzeau

Ceramium diaphanum (Lightfoot) Roth

Ceramium tenerrimum (G. Martens) Okamura
EE

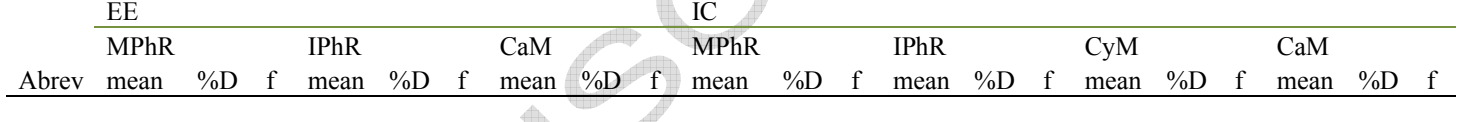

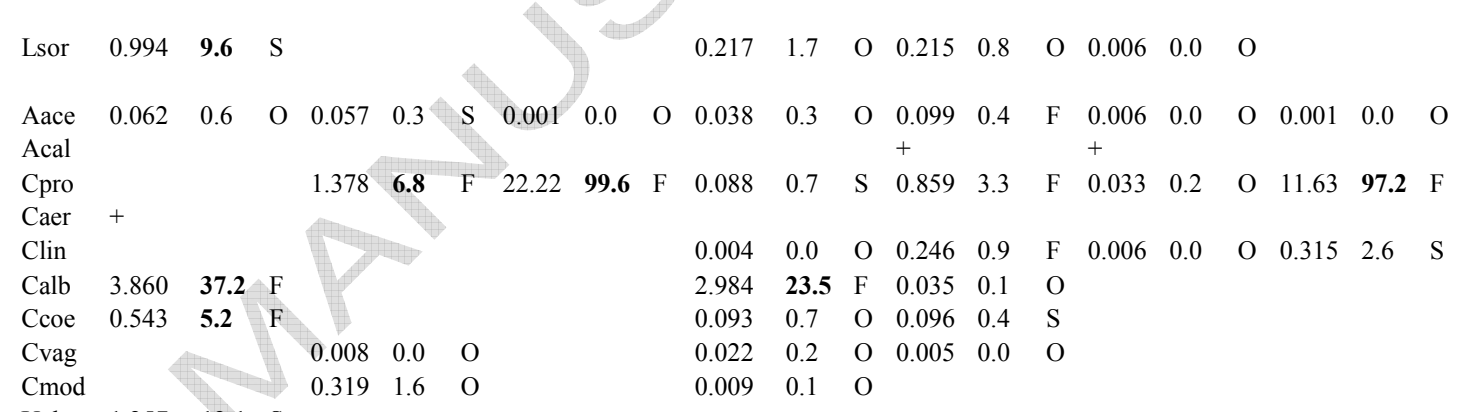

Ucla $1.257 \quad \mathbf{1 2 . 1} \mathrm{S}$

$\begin{array}{llll}\text { Ucom } & 0.285 & 2.7 & \mathrm{~S}\end{array}$

Uint

Urig

Vaeg

Vutr

$\begin{array}{lll}0.510 & 2.5 \quad \mathrm{~F}\end{array}$

$\begin{array}{llllll}0.040 & 0.3 & \mathrm{O} & 0.016 & 0.1 & \mathrm{O}\end{array}$

Cnod

Ccom

Cfoe

Dlin

Llev $\quad 0.022 \quad 0.2 \quad 0$

$\begin{array}{lll}0.166 & 0.8 & \mathrm{~S}\end{array}$

$\begin{array}{llll}\text { Slom } & 0.132 & 1.3 & \mathrm{O} \\ \text { Stri } & & \end{array}$ $+$

Acor

$\begin{array}{lllllll}\text { Aten } & 0.007 & 0.1 & \mathrm{O} & 0.014 & 0.1 & \mathrm{O}\end{array}$

$\begin{array}{llllllll}\text { Bfru } & & & & & & & \\ \text { Ccil } & 0.376 & 3.6 & \text { O } & 0.435 & 2.1 & \mathrm{O}\end{array}$

$\begin{array}{lllllll}\text { Ccil } & 0.376 & 3.6 & 0 & 0.435 & 2.1 & 0 \\ \text { Cdia } & 0.022 & 0.2 & \mathrm{O} & 0.008 & 0.0 & \mathrm{O}\end{array}$

$\begin{array}{lllllll}\text { Cten } & 0.082 & 0.8 & \mathrm{O} & 0.110 & 0.5 & \mathrm{O}\end{array}$ $\begin{array}{lll}0.011 & 0.0 & \mathrm{O}\end{array}$

$\begin{array}{llllllllllll}0.321 & 2.5 & \mathrm{~S} & 0.811 & 3.1 & \mathrm{~F} & 14.60 & \mathbf{9 8 . 9} & \mathrm{F} & 0.024 & 0.2 & \mathrm{O}\end{array}$

$\begin{array}{lllllllll}1.097 & \mathbf{8 . 6} & \mathrm{S} & 4.095 & \mathbf{1 5 . 6} & \mathrm{F} & 0.063 & 0.4 & \mathrm{O}\end{array}$

$\begin{array}{lllllllll}0.466 & 3.7 & \mathrm{~S} & 1.755 & \mathbf{6 . 7} & \mathrm{F} & 0.016 & 0.1 & \mathrm{O}\end{array}$

$\begin{array}{lllllll}0.054 & 0.4 & \mathrm{O} & 0.063 & 0.2 & \mathrm{~S}\end{array}$

$\begin{array}{llllll}0.201 & 1.6 & \mathrm{O} & 1.048 & 4.0 & \mathrm{~F}\end{array}$

$\begin{array}{lll}0.031 & 0.1 & \mathrm{O}\end{array}$

$\begin{array}{llllll}0.271 & 2.1 & \mathrm{O} & 0.063 & 0.2 & \mathrm{O}\end{array}$

$\begin{array}{llllll}0.005 & 0.0 & \mathrm{O} & 0.025 & 0.1 & \mathrm{O}\end{array}$ 
Champia parvula (C. Agardh) Harvey

Chondria capillaris (Hudson) M.J. Wynne

Chondrophycus tenerrimus (Cremades) G. Furnari, Boisset, Cormaci et Serio Dasya corymbifera J. Agardh

Falkenbergia rufolanosa Stadium

Herposiphonia secunda (C. Agardh) Ambronn

Hypnea musciformis (Wulfen) J.V. Lamouroux

Jania Rubens (Linnaeus) J.V. Lamouroux

Polysiphonia subulata (Ducluzeau) P.L. Crouan \& H.M. Crouan

Spyridia filamentosa (Wulfen) Harvey
Cpar

Ccap

$\begin{array}{llllllllllllllll}\text { Dcor } & 0.007 & 0.0 & \mathrm{O} & & & & & & & & & & & & \end{array}$

Hsec

Hmus

Jrub

Psub

Sr 14

$\begin{array}{ll}\text { B } & 10.38 \\ H^{\prime} & 2.53\end{array}$

$0.013 \quad 0.1 \quad 0$

$\begin{array}{lllllllll}0.851 & 6.7 & \mathrm{~S} & 1.042 & 4.0 & \mathrm{~F} & 0.012 & 0.1 & \mathrm{O}\end{array}$

$\begin{array}{llllll}0.137 & 1.1 & \mathrm{O} & 0.287 & 1.1 & \mathrm{~S}\end{array}$

$\begin{array}{lll}17.20 & \mathbf{8 4 . 7} & \mathrm{F} \\ 0.001 & 0.0 & \mathrm{O}\end{array}$

20.3

20.31
0.99

4
22.30

21
12.70

22

26.31

11
14.76

2.52

2.21

0.12

4

0.20 
Table 5. Results of mixed analysis of variance showing the effects of the factors season, local assemblage and their interaction (Season*Local_assemblage on the biomass, species richness and H' Shannon index of diversity of macrophyte assemblages at the three localities studied, indicating the factors at which significant variation exists. Results of Tukey (HSD) test are also shown indicating the homogeneous groups identified. See Tab. 3 and 4 for sample codes.

\begin{tabular}{|c|c|c|c|c|}
\hline & & $\begin{array}{l}\text { Biomass } \\
\mathrm{n}=165\end{array}$ & & \\
\hline Source & $\mathrm{df}$ & F-ratio & $\bar{p}$ & Tukey (HSD) \\
\hline$\overline{\text { SEASON }}$ & 4 & 0.776 & 0.543 & \\
\hline LOCAL_ASSEMBLAGE & 10 & 206.712 & 0.0001 & $\begin{array}{l}\text { CP_PM }>\text { CP_IPhR }> \\
\text { CP_MPhR=IC_CyM=IC_IPhR }=\text { EE_CaM= } \\
\text { EE_IPhR=CP_IScR }> \\
\text { IC_MPhR }=\text { IC_CaM=EE_MPhR }\end{array}$ \\
\hline
\end{tabular}

SEASON* LOCAL_ASSEMBLAGE Error

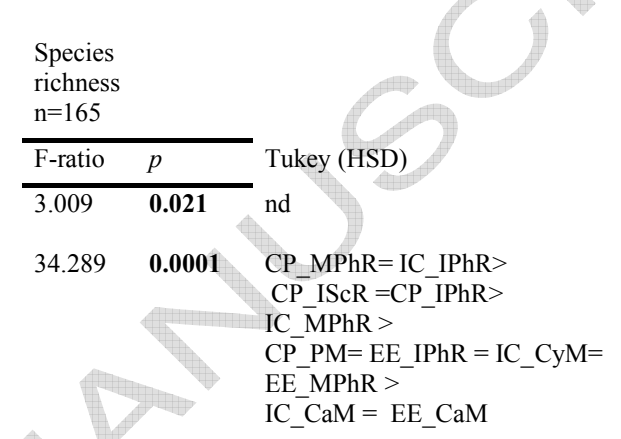

$1.275 \quad 0.163$

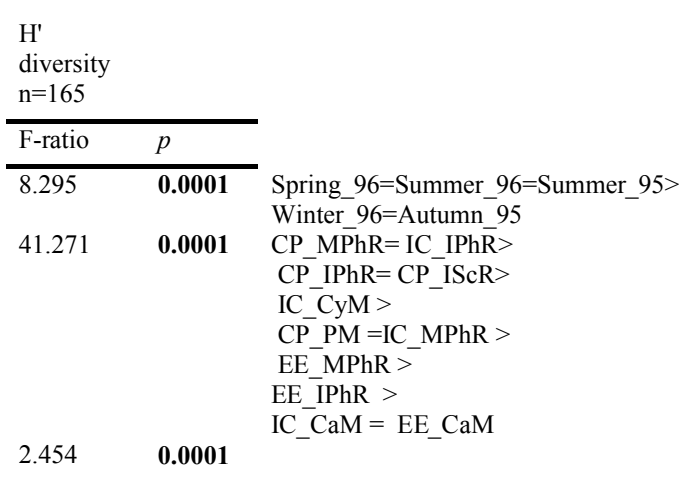

110


Table 6. Results of mixed analysis of variance showing the effects of the factors season, locality, assemblage and their interaction (Season*Locality; Season* Assemblage; Locality* Assemblage and Season* Locality*Assemblage) on the biomass, species richness and H' Shannon index of diversity of the midlittoral and infralittoral macrophyte photophilous assemblages on rock, indicating the factors at which significant variation exists (bold figures). Results of Tukey (HSD) test for individual factors are also shown indicating the homogeneous groups identified. (nd: non differentiated groups). Sample codes as in Table 3 and 4.

\begin{tabular}{|c|c|c|c|c|c|c|c|c|c|c|}
\hline & \multicolumn{3}{|c|}{ Biomass $\mathrm{n}=90$} & \multirow[b]{2}{*}{ Tukey (HSD) } & \multicolumn{2}{|c|}{ Species richness } & \multirow[b]{2}{*}{ _ Tukey (HSD) } & \multicolumn{2}{|c|}{$\mathrm{H}^{\prime} \quad \nabla=$} & \multirow[b]{2}{*}{ - Tukey (HSD) } \\
\hline Source & df & F-ratio & $p$ & & F-ratio & $p$ & & F-ratio & $p$ & \\
\hline SEASON & 4 & 1.722 & 0.157 & & 2.928 & 0.028 & nd & 8.369 & 0.0001 & Spring_96=Summer_96=Summer_95 $>$ Winter_96=Autumn_95 \\
\hline LOCALITY & 2 & 17.381 & 0.0001 & $\mathrm{CP}>\mathrm{IC}=\mathrm{EE}$ & 41.75 & 0.0001 & $\mathrm{CP}>\mathrm{IC}>\mathrm{EE}$ & 31.813 & 0.0001 & $\mathrm{CP}=\mathrm{IC}>\mathrm{EE}$ \\
\hline ASSEMBLAGE & 1 & 15.392 & 0.0001 & $\mathrm{IPhR}>\mathrm{MPhR}$ & 0.612 & 0.437 & & 1.8 & 0.185 & \\
\hline SEASON*LOCALITY & 8 & 2.402 & 0.026 & & 1.035 & 0.42 & & 0.682 & 0.705 & \\
\hline SEASON*ASSEMBLAGE & 4 & 1.218 & 0.313 & & 0.479 & 0.751 & $\phi$ & 0.764 & 0.553 & \\
\hline LOCALITY*ASSEMBLAGE & 2 & 0.635 & 0.534 & & 24.399 & 0.0001 & & 17.648 & 0.0001 & \\
\hline SEASON*LOCALITY*ASSEMBLAGE & 8 & 0.987 & 0.455 & & 1.786 & 0.098 & & 3.629 & 0.002 & \\
\hline Error & 60 & & & & & & & & & \\
\hline
\end{tabular}


Table 7. Results of mixed analysis of variance showing the effects of the factors season, locality, assemblage and their interaction (Season*Locality; Season*Assemblage; Locality*Assemblage and Season*Locality*Assemblage) on the biomass, species richness and H' Shannon index of diversity in the Caulerpa prolifera meadow, indicating the factors at which significant variation exists .. Results of Tukey (HSD) test for individual factors are also shown indicating the homogeneous groups identified. ( $>=$ is used to indicate that only the extremes differ significantly).

Biomass

\begin{tabular}{|c|c|c|c|c|c|c|}
\hline & & Biomas & & \multirow[b]{2}{*}{ Tukey (HSD) } & \multicolumn{2}{|c|}{ Species richness } \\
\hline Source & $\mathrm{df}$ & F-ratio & $p$ & & F-ratio & $p$ \\
\hline SEASON & 4 & 4.039 & 0.015 & Winter_96 $>=$ Spring_96=Autumn_95=Summer_95 $>=$ Summer_96 & 1.125 & 0.373 \\
\hline LOCALITY & 1 & 55.473 & 0.0001 & $\mathrm{EE}>\mathrm{IC}$ & 0.333 & 0.57 \\
\hline SEASON*LOCALITY & 4 & 2.69 & 0.061 & & 2.208 & 0.105 \\
\hline Error & 20 & & & & 80 & \\
\hline
\end{tabular}

$\underline{H^{\prime} \text { diversity }}$

\begin{tabular}{llll} 
Tukey (HSD) & F-ratio & $p$ & Tukey (HSD) \\
\cline { 2 - 3 } & 2.36 & 0.088 & \\
7.819 & 0.011 & IC $>$ EE \\
& 3.146 & 0.037 &
\end{tabular}

- -


Table 8. Results of mixed analysis of variance showing the effects of the factors season, local_assemblage and their interaction (Season*Local_Assemblage) on the biomass, of frequent species, indicating $F$ va lues and significance levels. ${ }^{*} p<0.05 ; \quad * * p<0.01$; $* * * p<0.005 ; \quad * * * * p<0.001 ;$ ns: not significant.

\begin{tabular}{|c|c|c|c|c|}
\hline Species & Abrev. & SEASON & LOCAL_ASSEMBLAGE & SEASON*LOCAL_ASSEMBLAGE \\
\hline Acetabularia acetabulum & Aace & $6.365 * * * *$ & $3.621 * * *$ & $3.302 * * * *$ \\
\hline Caulerpa prolifera & Cpro & $2.745 *$ & $114.808 * * * *$ & $2.933 *$ \\
\hline Ceramium ciliatum & Ccil & $2.863 *$ & $0.274 \mathrm{~ns}$ & $0.86 \mathrm{~ns}$ \\
\hline Ceramium diaphanum & Cdia & $1.202 \mathrm{~ns}$ & $0.234 \mathrm{~ns}$ & $0.949 \mathrm{~ns}$ \\
\hline Ceramium tenerrimum & Cten & $5.432 * * *$ & $0.345 \mathrm{~ns}$ & $0.345 \mathrm{~ns}$ \\
\hline Champia parvula & Cpar & $0.79 \mathrm{~ns}$ & $0.162 \mathrm{~ns}$ & $1.21 \mathrm{~ns}$ \\
\hline Chondria capillaris & Ccap & $0.613 \mathrm{~ns}$ & $4.402 * * *$ & $2.063 *$ \\
\hline Chondrophycus tenerrimus & Chte & $2.78 *$ & $41.414 * * * *$ & $1.271 \mathrm{~ns}$ \\
\hline Cladophora albida & Calb & $2.373 \mathrm{~ns}$ & $4.977 *$ & $2.935 *$ \\
\hline Cladophora coelothrix & Ccoe & $1.008 \mathrm{~ns}$ & $1.066 \mathrm{~ns}$ & $0.973 \mathrm{~ns}$ \\
\hline Cladophora vagabunda & Cvag & $0.794 \mathrm{~ns}$ & $0.408 \mathrm{~ns}$ & $1.041 \mathrm{~ns}$ \\
\hline Cladophoropsis modonensis & Cmod & $2.023 \mathrm{~ns}$ & $1.197 \mathrm{~ns}$ & $1.291 \mathrm{~ns}$ \\
\hline Cladostephus spongiosus & Cspo & $0.679 \mathrm{~ns}$ & $15.886 * * * *$ & $0.643 \mathrm{~ns}$ \\
\hline Corallina elongata & Celo & $0.878 \mathrm{~ns}$ & $0.774 \mathrm{~ns}$ & $1.057 \mathrm{~ns}$ \\
\hline Cymodocea nodosa & Cnod & $1.48 \mathrm{~ns}$ & $119.785 * * * *$ & $1.713 \mathrm{~ns}$ \\
\hline Cystoseira compressa & Ccom & $9.488 * * * *$ & $21.087^{* * * *}$ & $1.438 \mathrm{~ns}$ \\
\hline Cystoseira foeniculacea f. tenuiramosa & Cfoe & $7.77 * * * *$ & $24.82 * * * *$ & $1.804 \mathrm{~ns}$ \\
\hline Dasya corymbifera & Dcor & $1.144 \mathrm{~ns}$ & $0.798 \mathrm{~ns}$ & $0.9 \mathrm{~ns}$ \\
\hline Dictyota fasciola & Dfas & $3.496 *$ & $3.779 \mathrm{~ns}$ & $3.531 *$ \\
\hline Dictyota linearis & Dlin & $3.781 * *$ & $2.537 \mathrm{~ns}$ & $2.28 *$ \\
\hline Falkenbergia rufolanosa & Fruf & $2.042 \mathrm{~ns}$ & $0.605 \mathrm{~ns}$ & $2.298 *$ \\
\hline Haliptilon virgatum & Hvir & $2.896 *$ & $29.688 * * * *$ & $2.896 * *$ \\
\hline Halopteris filicina & Hfil & $0.593 \mathrm{~ns}$ & $18.794 * * * *$ & $0.272 \mathrm{~ns}$ \\
\hline Jania rubens & Jrub & $3.438 *$ & $24.07 * * * *$ & $2.241 * * *$ \\
\hline Jania rubens var cor & Jcor & $2.896 *$ & $29.688 * * * *$ & $2.896 * *$ \\
\hline Laurencia obtusa & Lobt & $0.996 \mathrm{~ns}$ & $1.16 \mathrm{~ns}$ & $1.099 \mathrm{~ns}$ \\
\hline Liagora viscida & Lvis & $1.926 \mathrm{~ns}$ & $1.03 \mathrm{~ns}$ & $0.628 \mathrm{~ns}$ \\
\hline Lyngbia sordida & Lsor & $1.162 \mathrm{~ns}$ & $1.671 \mathrm{~ns}$ & $1.318 \mathrm{~ns}$ \\
\hline Padina pavonica & Ppav & $5.77 * * * *$ & $6.865 * * * *$ & $2.112 * *$ \\
\hline Peyssonnelia squamaria & Psqu & $0.142 \mathrm{~ns}$ & $70.693 * * * *$ & $0.119 \mathrm{~ns}$ \\
\hline Posidonia oceanica & Poce & $1.088 \mathrm{~ns}$ & - & - \\
\hline Scytosiphon lomentaria & Slom & $1.927 \mathrm{~ns}$ & - & - \\
\hline Stypocaulon scoparium & Ssco & $4.545 * * *$ & $26.023 * * * *$ & $0.979 \mathrm{~ns}$ \\
\hline Ulva clathrata & Ucla & $1.762 \mathrm{~ns}$ & - & - \\
\hline Ulva intestinalis & Uint & $4.219 * *$ & $10.083 * * * *$ & $4.511 * * *$ \\
\hline Valonia aegagropila & Vaeg & $1.651 \mathrm{~ns}$ & $0.182 \mathrm{~ns}$ & $0.311 \mathrm{~ns}$ \\
\hline
\end{tabular}

